\title{
Strategies for improving the acceptability and acceptance of the copper intrauterine device (Review)
}

\author{
Arrowsmith ME, Aicken CRH, Saxena S, Majeed A
}

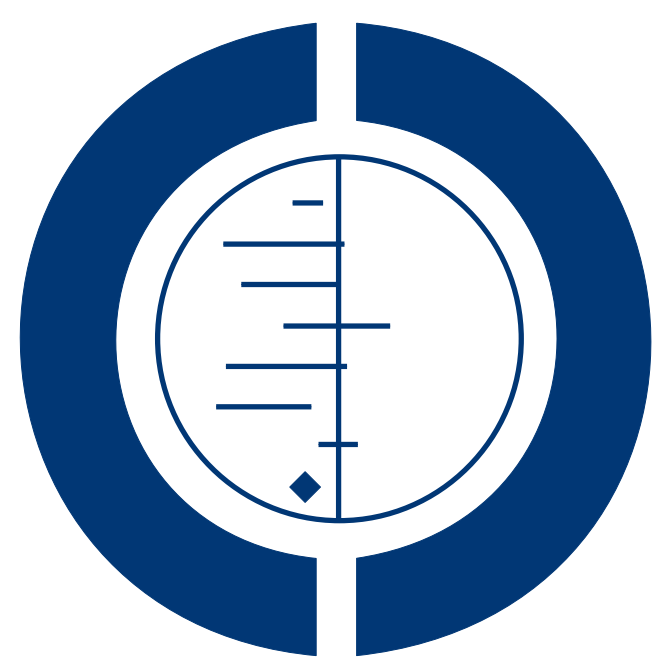

\section{THE COCHRANE COLLABORATION $^{\circledR}$}

This is a reprint of a Cochrane review, prepared and maintained by The Cochrane Collaboration and published in The Cochrane Library 2012, Issue 3

http://www.thecochranelibrary.com

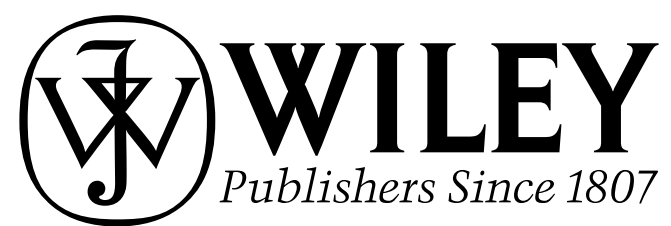

Strategies for improving the acceptability and acceptance of the copper intrauterine device (Review)

Copyright (C) 2012 The Cochrane Collaboration. Published by John Wiley \& Sons, Ltd. 
TABLE OF CONTENTS

HEADER . . . . . . . . . . . . . . . . . . . . . . . . . . . . . . . . . . . . . . . 1

ABSTRACT . . . . . . . . . . . . . . . . . . . . . . . . . . . . . . . . . . . . . . . . . . . . . 1

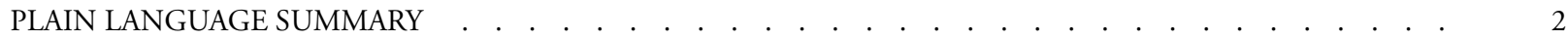

SUMMARY OF FINDINGS FOR THE MAIN COMPARISON . . . . . . . . . . . . . . . . . . . . 2

BACKGROUND . . . . . . . . . . . . . . . . . . . . . . . . . . . . . . . . . . . . . . 4

OBJECTIVES . . . . . . . . . . . . . . . . . . . . . . . . . . . . . . . . . . . . . . . . . . . . . . . 4

METHODS . . . . . . . . . . . . . . . . . . . . . . . . . . . . . . . . . . . . . . 4

RESULTS . . . . . . . . . . . . . . . . . . . . . . . . . . . . . . . . . . . . . . . 6

Figure 1. . . . . . . . . . . . . . . . . . . . . . . . . . . . . . . . . . . . . . 9

Figure 2. . . . . . . . . . . . . . . . . . . . . . . . . . . . . . . . . . . . . . . 11

Figure 3. . . . . . . . . . . . . . . . . . . . . . . . . . . . . . . . . . . . . . 11

Figure 4. . . . . . . . . . . . . . . . . . . . . . . . . . . . . . . . . . . . . . 12

Figure 5. . . . . . . . . . . . . . . . . . . . . . . . . . . . . . . . . . . . 13

Figure 6. . . . . . . . . . . . . . . . . . . . . . . . . . . . . . . . . . . . . . 14

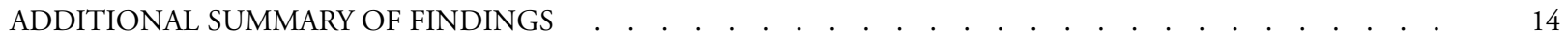

DISCUSSION . . . . . . . . . . . . . . . . . . . . . . . . . . . . . . . . . . . . . 19

AUTHORS' CONCLUSIONS . . . . . . . . . . . . . . . . . . . . . . . . . . . . . . . . 19

ACKNOWLEDGEMENTS . . . . . . . . . . . . . . . . . . . . . . . . . . . . . . . . . . . . . . . . $\quad 20$

REFERENCES . . . . . . . . . . . . . . . . . . . . . . . . . . . . . . . . . . . . . 20

CHARACTERISTICS OF STUDIES . . . . . . . . . . . . . . . . . . . . . . . . . . . . . . . . . . . . . . 23

DATA AND ANALYSES . . . . . . . . . . . . . . . . . . . . . . . . . . . . . . . . . . . . . . . . . . . . 38

Analysis 1.1. Comparison 1 Effectiveness of community-based family planning programme: community workers versus control, Outcome 1 Uptake of IUD. . . . . . . . . . . . . . . . . . . . . . . . . . . . . . . . . . . 39

Analysis 1.2. Comparison 1 Effectiveness of community-based family planning programme: community workers versus control, Outcome 2 Knowledge of IUD. . . . . . . . . . . . . . . . . . . . . . . . . . . . . . . . 40

Analysis 2.1. Comparison 2 Effectiveness of contraceptive counselling provision among postpartum population: postnatal counselling versus control, Outcome 1 Uptake of IUD. . . . . . . . . . . . . . . . . . . . . . . . . . 41

Analysis 3.1. Comparison 3 Effectiveness of contraceptive counselling provision among postpartum population (shortterm): antenatal counselling versus control, Outcome 1 Uptake of IUD.

Analysis 4.1. Comparison 4 Effectiveness of family planning counselling among postabortion population, Outcome 1

Uptake of IUD. . . . . . . . . . . . . . . . . . . . . . . . . . . . . . . . . . 43

HISTORY . . . . . . . . . . . . . . . . . . . . . . . . . . . . . . 43

CONTRIBUTIONS OF AUTHORS . . . . . . . . . . . . . . . . . . . . . . . . . . . . . . . . . . . . . . 43

DECLARATIONS OF INTEREST . . . . . . . . . . . . . . . . . . . . . . . . . . . . . . . . . . . . . $\quad . \quad 43$

SOURCES OF SUPPORT . . . . . . . . . . . . . . . . . . . . . . . . . . . . . . . . . 44 


\title{
[Intervention Review]
}

\section{Strategies for improving the acceptability and acceptance of the copper intrauterine device}

\author{
Myat E Arrowsmith ${ }^{1}$, Catherine RH Aicken ${ }^{2}$, Sonia Saxena ${ }^{1}$, Azeem Majeed ${ }^{1}$ \\ ${ }^{1}$ Department of Primary Care and Public Health, Imperial College London, London, UK. ${ }^{2}$ University College London, Centre for \\ Sexual Health \& HIV Research, London, UK \\ Contact address: Myat E Arrowsmith, Department of Primary Care and Public Health, Imperial College London, Charing Cross \\ Hospital, St. Dunstan's Road, London, W6 8RP, UK. emma.arrowsmith08@imperial.ac.uk.
}

Editorial group: Cochrane Fertility Regulation Group.

Publication status and date: New, published in Issue 3, 2012.

Review content assessed as up-to-date: 2 September 2011.

Citation: Arrowsmith ME, Aicken CRH, Saxena S, Majeed A. Strategies for improving the acceptability and acceptance of the copper intrauterine device. Cochrane Database of Systematic Reviews 2012, Issue 3. Art. No.: CD008896. DOI: 10.1002/14651858.CD008896.pub2.

Copyright (C) 2012 The Cochrane Collaboration. Published by John Wiley \& Sons, Ltd.

\section{A B S T R A C T}

\section{Background}

Intrauterine devices (IUDs) are highly effective and are the most widely used reversible contraceptive method in the world. However, in developed countries IUDs are among the least common methods of contraception used. We evaluated the effect of interventions to increase uptake of the copper IUD, a long-acting, reversible contraceptive method.

\section{Objectives}

To determine effectiveness of interventions to improve uptake and continuation of the copper IUD.

\section{Search methods}

We searched the Cochrane Central Register of Controlled Trials (CENTRAL), MEDLINE, EMBASE, POPLINE, PsycINFO, PubMed, ClinicalTrials.gov, International Clinical Trials Registry Platform (ICTRP) and OpenSIGLE. We also handsearched references of relevant reviews and included studies.

\section{Selection criteria}

We included randomised controlled trials (RCTs) and controlled before and after studies of interventions which measured use and uptake of contraception including copper IUD as an outcome.

\section{Data collection and analysis}

Two authors independently screened the search results for relevant studies and extracted data from included studies. We used RevMan 5.1 to calculate Peto odd ratios (OR) with $95 \%$ confidence intervals (CI) for dichotomous outcomes. We conducted meta-analysis by pooling data for similar types of intervention where possible. We used the GRADE system to evaluate the quality of evidence.

\section{Main results}

Nine studies representing 7960 women met our inclusion criteria, including seven randomised controlled trials and two controlled before and after studies that reported IUD uptake postintervention. We evaluated the quality of evidence as moderate to low. Three studies on contraceptive counselling and referrals by community workers showed an increase in uptake of the IUD among intervention 
groups (Peto OR 2.00; 95\% CI 1.40 to 2.85). Two studies on antenatal contraceptive counselling also favoured the intervention groups (Peto OR 2.33; 95\% CI 1.39 to 3.91). One study on postnatal couple contraceptive counselling also showed an increase in IUD uptake compared to control (Peto OR 5.73; 95\% CI 3.59 to 9.15). The results of one study evaluating postnatal home visits and two studies on enhanced postabortion contraceptive counselling did not reach statistical significance.

\section{Authors' conclusions}

Community-based interventions and antenatal contraceptive counselling improved uptake of copper IUD contraception. Since the copper IUD is one of the most effective reversible contraceptive methods, primary care and family planning and practitioners could consider adopting these interventions. Although our review suggests these interventions are clinically effective, a cost-benefit analysis may be required to evaluate applicability.

\section{PLAIN LANGUAGESUMMARY}

\section{Ways to increase use of non-hormonal long-acting birth control}

The copper intrauterine device (copper IUD) is a highly-effective non-hormonal type of birth control, and is the most commonly used method in the world. However, use of the copper IUD is low in countries with relatively high rates of unintended pregnancy, such as the United Kingdom and United States. Our review looked at studies of different interventions to improve use of the copper IUD.

We did computer searches for relevant studies and looked at the reference lists of study reports to identify more studies. We found nine studies of moderate to low quality. Three studies on contraceptive counselling and referrals by community workers showed an increase in use of the copper IUD. Two studies on antenatal contraceptive counselling and one study on postnatal couple counselling, with provision of an information leaflet before being discharged from the maternity ward, also showed an increase in use of the copper IUD. A study on postnatal home visits and two studies on enhanced postabortion contraceptive counselling did not show an increase in use of the copper IUD. More high-quality research is needed to look at the longer-term effectiveness of interventions to improve use of the copper IUD. 


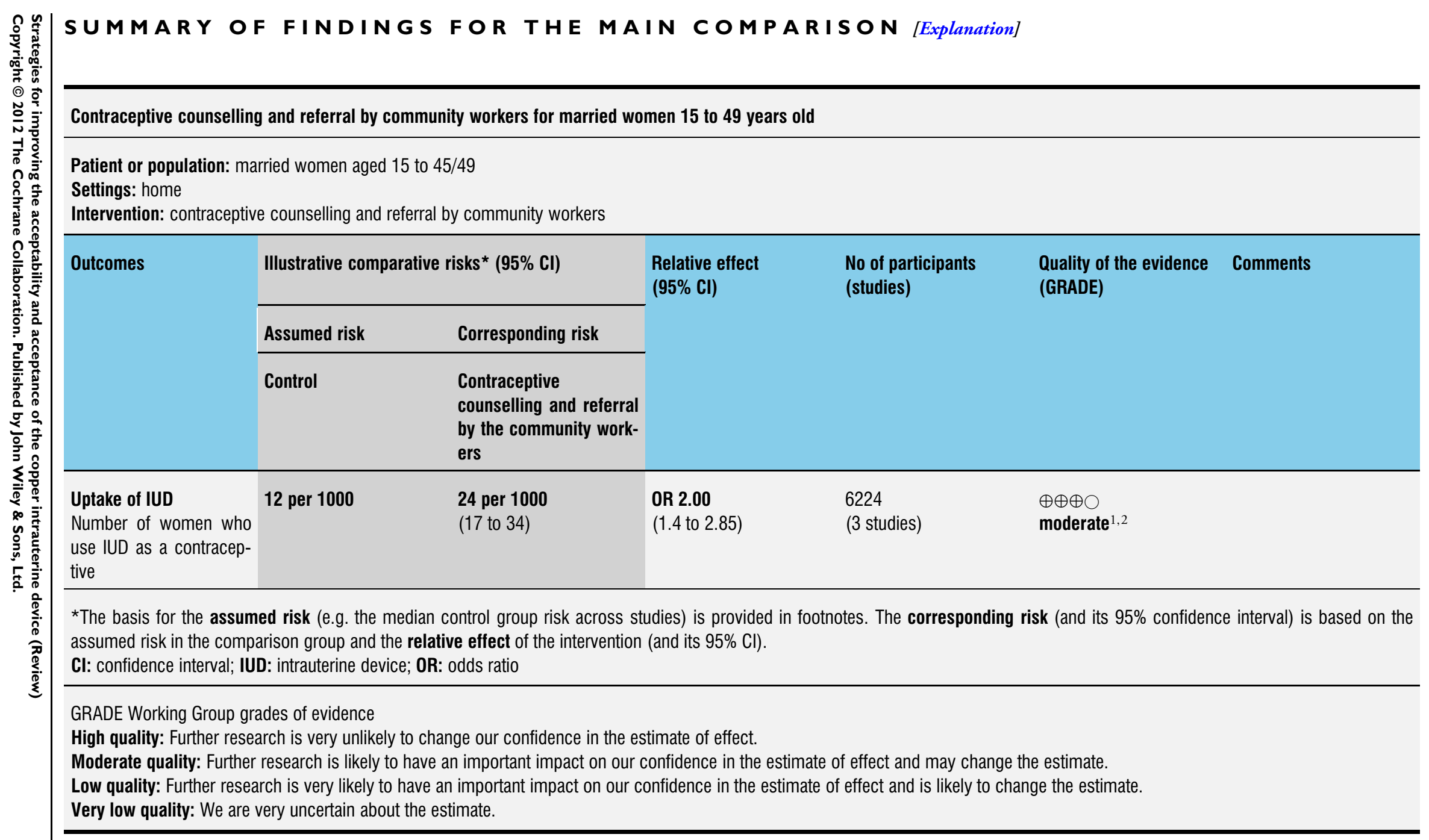

${ }^{1}$ These studies have 'high' risk of bias for two categories or higher.

${ }^{2}$ Unexplained heterogeneity of $\mathrm{L}^{2}=86 \%$; two studies suggested benefit, however the confidence intervals do not overlap. 


\section{B A C K G R O U N D}

\section{Description of the condition}

Unintended or unplanned pregnancies due to contraceptive failures are associated with method efficacy and user-adherence factors, such as incorrect and inconsistent use (Kost 2008; Trussell 2004; Trussell 2009). Non-hormonal intrauterine devices (IUDs) or copper IUDs are considered to be highly effective in preventing pregnancy, with failure rates being less then $1 \%$, and low reliance on user adherence (Mansour 2010; Trussell 2009). Copper IUDs are also considered an effective method of emergency contraception (Cheng 2008).

\section{Description of the intervention}

IUDs are the most widely used reversible contraceptive method in the world (at 14.2\% in 2009 and 15.4\% in 2007), followed by oral contraceptive pills and male condoms (United Nations 2008; United Nations 2009). An estimated 175 million women worldwide were using copper IUDs and intrauterine systems (IUS) in 2007, of whom just 5 million used hormonal IUS (Sivin 2010). This high prevalence is attributed to the copper IUD being the most commonly used method in developing countries, particularly China (United Nations 2008; United Nations 2009).

Contraceptive choices and use or non-use of particular methods are influenced by, and associated with, a number of complex factors. These include socio-demographic characteristics, knowledge, information, lifestyle need, perceptions of women, availability and accessibility of services, healthcare providers' attitude and knowledge; and also other external factors such as legal restrictions on the availability of abortion services and reproductive rights (Belfield 2009; Campbell 2006; Frost 2008; Oddens 1997; Wellings 2007).

\section{How the intervention might work}

The quality of family planning counselling is an important component in increasing contraceptive uptake; interventions such as specialist contraceptive counselling can increase uptake of longterm contraceptive methods (Davie 1996). Interventions could be client- or provider-focused and may include provision of educational materials or programmes, peer or multi-component counselling, medical interventions to increase acceptability, provider education programmes and checklist tools.

\section{Why it is important to do this review}

Although IUDs are the most commonly used reversible contraceptive method in the world, the use of IUDs is much lower (at 9\%) in developed countries, where the most commonly used methods are oral contraceptive pills and condoms. Furthermore, national surveys of contraceptive use in the United Kingdom show that the use of long-acting reversible contraceptives (LARCs) including copper IUDs is lower than in many other European countries (Lader 2009). A large study of contraceptive use among 12,000 women (age between 15 to 49 years old) across five European countries also shows that oral contraceptive pills and condoms are the most commonly used methods in Europe, with the United Kingdom showing the lowest use of IUDs (Haimovich 2009; Skouby 2004). Interventions or strategies to improve acceptance and acceptability of hormonal contraceptives were assessed in a previous Cochrane systematic review (Halpern 2006). This systematic review will examine whether client- and provider-interventions could increase uptake or continuation of a non-hormonal long-acting reversible contraceptive method, namely copper IUDs.

\section{O B J E C T I V E S}

The objective of this review was to determine the effectiveness of interventions to improve uptake and continuation of the copper IUD.

\section{METHODS}

\section{Criteria for considering studies for this review}

\section{Types of studies}

We considered studies which are randomised controlled trials, controlled clinical trials and controlled before and after studies comparing an intervention with standard care or comparing multiple interventions, and interrupted time series that reported objectively measured outcomes concerning the effect of interventions to improve uptake and continuation of contraception including the copper IUD.

\section{Types of participants}

Eligible participants were women of reproductive age. We excluded trials with women who have specific health conditions such as diabetes or HIV.

\section{Types of interventions}

Eligible interventions were designed to improve contraceptive use or to reduce unplanned pregnancy, and included contraceptive and family planning counselling; information provision in leaflets and other formats; decision aids; education and training programmes 
for the providers. We considered interventions which aimed to improve contraceptive use or to reduce unplanned pregnancy through improving contraceptive use; and we included all studies which measured IUD uptake as an outcome.

\section{Types of outcome measures}

\section{Primary outcomes}

The primary outcome of interest was a change in uptake or use of the copper IUD postintervention.

\section{Secondary outcomes}

Additional outcomes intended to be included were continuation of copper IUD, which is measured by discontinuation or removal rate; knowledge of contraception (copper IUD), reasons for use or non-use of contraceptive (copper IUD) and reasons for removal if available.

\section{Search methods for identification of studies}

We searched the following computerised databases: the Cochrane Central Register of Controlled Trials (CENTRAL), PubMed, MEDLINE, EMBASE, POPLINE, PsycINFO, ClinicalTrials.gov, the World Health Organization (WHO) International Clinical Trials Registry Platform (ICTRP) and OpenSIGLE (System for Information on Grey Literature in Europe) using the following key words: contracepti*, birth control, uptake, use, acceptance.

\section{Electronic searches}

We used the following search strategies for each computerised databases.

- CENTRAL search used the search terms contracepti* OR birth?control AND (compliance OR accept* OR adherence OR continu* OR discontinu* OR use OR uptake)); search restricted to Cochrane Reviews, Other Reviews, Clinical Trials, and date range limited to 1990-2010.

- PubMed search used the search terms (contracepti* OR "birth control") AND (intervention AND (compliance OR acceptance OR adherence OR continu* OR discontinu* OR use OR uptake)).

- POPLINE used the search terms (contracepti* / birth control) \& (intervention \& (accept* / adherence / continu* / discontinu* / use / uptake).

- EMBASE, PsycINFO and MEDLINE (via OVID) searches used the search terms (contracepti* OR birth control) AND (intervention AND (compliance OR accept* OR adherence OR continu*)); search limited to humans, publication year 19902010.
- ClinicalTrials.gov search used the search terms contraceptive OR contraception OR birth control OR family planning; search limited by gender, not seniors 66+.

- WHO International Clinical Trials Registry Platform (ICTRP) search used the search terms contraception OR contraceptive OR in the Condition search field.

The general term 'contraception' or 'contraceptive' was to ensure that the interventions with a primary or secondary outcome of contraceptive use or uptake of the participants including copper IUD were not missed during the search. The terms 'birth control' and 'family planning' were used as some studies were listed under these keywords rather than contraception or IUD.

\section{Searching other resources}

We examined studies listed in the relevant reviews, systematic reviews and references of included studies. We contacted investigators of completed unpublished studies to obtain data. We also contacted the first authors of identified and included studies to request additional information about studies where a breakdown by types of contraceptive used was not reported.

\section{Data collection and analysis}

\section{Selection of studies}

The primary and secondary authors screened the titles and abstracts from the literature search to identify relevant studies. The two authors retrieved and screened the full text of all the relevant studies independently using our inclusion and exclusion criteria. We included all studies published between January 1990 and June 2011 as specified in the protocol. We excluded studies which did not present any of the outcome measures. We also excluded studies which focused on women with chronic health conditions such as diabetes or HIV.

\section{Data extraction and management}

Two authors independently extracted data from the studies. We resolved discrepancies between the two independent reviewing authors through discussion and the involvement of a third author when needed. We used Review Manager 5.1 to analyse the data (RevMan 2011). We found a few studies which made no distinction between levonorgestrel-releasing intrauterine device (LNGIUD) and copper intrauterine device. We contacted the primary authors of these studies to clarify ambiguities and to seek additional data as required. We excluded studies in which the primary authors were not able to provide separate copper IUD uptake data. 


\section{Assessment of risk of bias in included studies}

We assessed the biases and risk of biases using a domain-based evaluation as recommended by the Cochrane Handbook for Systematic Reviews of Interventions (Higgins 2009). We considered factors such as study design, randomisation method (where applicable), allocation concealment, blinding and losses to follow-up. We assessed randomised and non-randomised studies using the same dimensions which included selection bias (concerning comparability of groups, confounding and adjustment), performance bias (concerning the fidelity of the interventions, and quality of the information regarding who received what interventions, including blinding of participants and healthcare providers), detection bias (concerning unbiased and correct assessment of outcome, including blinding of assessors), attrition bias (concerning completeness of sample, follow-up and data) and reporting bias (concerning publication biases and selective reporting of results).

\section{Measures of treatment effect}

The primary outcome, uptake, is measured by the number of women using, or that used, copper IUDs during and postintervention. We calculated the effect of intervention using Peto odds ratios (OR) with $95 \%$ confidence interval $(\mathrm{CI})$. We intended to measure continuation of use of copper IUDs by the number of women who discontinued use or removed the method.

\section{Unit of analysis issues}

We followed the method of combining groups as recommended in the Cochrane Handbook for Systematic Reviews of Interventions in cases of cluster-randomised trials and cross-over trials. For trials comparing more than two intervention groups, we assessed the relevant intervention group.

\section{Dealing with missing data}

Where applicable, we contacted the original investigators of the study to request missing data and results, or results shown in diagrams without specific numbers for analysis. We carried out the analysis according to intention-to-treat (ITT) for studies where we were not able to receive information on missing data from the authors. Where any assumptions were made on the missing data, such as missing at random or assumed to have a particular value, we included the potential impact of missing data in the Discussion section of the review (Higgins 2009).

\section{Assessment of heterogeneity}

We assessed the outcome data for heterogeneity using the $\mathrm{I}^{2}$ statistic. We did not pool the results if there was significant heterogeneity present. We performed subgroup analyses to explore possible causes of heterogeneity in the first instance.

\section{Assessment of reporting biases}

We used funnel plots to identify possible biases. We assessed all reporting biases at the study level as recommended in Cochrane Handbook for Systematic Reviews of Interventions (Chan 2005; Kirkham 2010). The assessment results of reporting biases are included within the 'Risk of bias' tables.

\section{Data synthesis}

We analysed data with Review Manager 5.1 (RevMan 2011). All outcomes were dichotomous. For the number of women who used the IUD postintervention we used the Peto odds ratio (OR) due IUD uptake being a rare outcome. We used a Mantel-Haenszel odds ratio for the secondary outcome, knowledge. We grouped studies on the basis of intervention type, participant characteristics and study setting.

\section{Subgroup analysis and investigation of heterogeneity}

We conducted subgroup analyses by intervention type, participant characteristics and study setting.

\section{Sensitivity analysis}

We planned to investigate whether the treatment effect size would vary by studies excluded due to design or methods. We compared the results of fixed and random-effects models.

\section{RES U L T S}

\section{Description of studies}

See: Characteristics of included studies; Characteristics of excluded studies; Characteristics of ongoing studies.

See: Characteristics of included studies; Characteristics of excluded studies; Characteristics of ongoing studies.

\section{Results of the search}

Our search located 1347 trials registered with ClinicalTrials.gov; 221 trials registered with WHO International Clinical Trials Registry Platform; 12,353 articles via POPLINE and OVID for EMBASE, MEDLINE and PsycINFO; and 1573 studies via CENTRAL. We also located 40 potentially relevant studies through previous reviews found via the search. 


\section{Included studies}

A total of nine studies, representing 7960 women (4960 in the intervention groups and 3009 in the control groups), met our inclusion criteria. Although we retrieved a substantial number of studies which aimed to improve contraceptive use, we found very few studies with IUD use results. The studies included were published in peer-reviewed journals (Bashour 2008; Douthwaite 2005; Ferreira 2010; Jahanfar 2005; Kambo 1994; Saeed 2008; Schunmann 2006; Smith 2002; Soliman 1999).

Bashour 2008 conducted a randomised controlled trial to assess the effectiveness of a community-based intervention, home visits to postpartum patients who recently gave birth at the Maternity Teaching Hospital in Damascus, Syria. A total of 876 women were recruited and randomly allocated to three groups, Group A ( $\mathrm{n}=$ $285)$ with four home visits, Group B ( $\mathrm{n}=294)$ with one home visit, and Group C the control group $(\mathrm{n}=297)$ with no home visit. Registered midwives who received special training carried out home visits to the intervention groups to provide emotional support, examine mother and child, educate the mother and discuss choices and plans for family planning.

Douthwaite 2005 evaluated the impact of the Lady Health Worker Programme (LHWP) on the uptake of modern contraceptive methods. The Lady Health Workers (LHW) are trained community-based female workers attached to a government health facility; the doorstep family planning services intervention includes motivating women to practise family planning, providing oral contraceptive pills and condoms, and referring for injections, IUD and sterilisation. Data from a random sample survey of 4277, of which 3346 married women were from the intervention area and 931 from the control area, were analysed for current use of reversible modern methods postintervention. Women who had undergone sterilisation were excluded from the study.

Ferreira 2010 performed a randomised control trial to assess the effectiveness of personalised postabortion counselling on acceptability and use of contraceptive methods by low-income women from the northeast region of Brazil. Women were recruited within one to two weeks after the abortion and followed for a period of six months. A total of 246 women were enrolled and randomly allocated to the intervention and control group equally $(\mathrm{n}=123$ for each arm). The intervention group received 30 minutes of personalised and comprehensive face-to-face contraceptive counselling, and the control group received standard care, which is 30 to 40 minutes of educational group counselling.

Jahanfar 2005 studied the impact of community-based distribution (CBD) on contraceptive knowledge, use and continuation among non-pregnant married women in suburbs of Hamedan City, Iran. The intervention (CBD) group received five visits, the first two and the last visit were by a midwife and interval visits by a trained distribution agent (DA) at home. DAs were trained by the midwife on the Johns Hopkins University checklists for family planning programmes and the GATHER (Greet, Ask, Tell, Help, Explain, Return) guidelines. Pamphlets and written materi- als were also provided for distribution. The control group received standard care of two visits by a midwife, one at the beginning of the trial and one at month six, both without contraceptive counselling or provision. In addition to contraceptive counselling, the CBD group also received oral contraceptive pills, condoms and injectable contraceptives if required, as well as a referral letter to the nearest family planning clinic for those who chose intrauterine device, tubectomy or vasectomy. Stratified random sampling was used in this controlled field trial; 100 participants were enrolled for the CBD and 200 were in the control group (with three lost to follow-up).

Kambo 1994 conducted a controlled before and after pilot study to explore the feasibility of using traditional practitioners to promote family planning in Uttar Pradesh, India. Two blocks were matched for key variables; 22 traditional practitioners in the intervention block were trained to provide contraceptive counselling and received a monthly honorarium for the provision. Cross-sectional surveys were carried out before and after the intervention in both control and intervention villages. A total of 1000 women were surveyed in the intervention group prior to the intervention and 800 after the intervention; 850 women each in the control group before and after the intervention.

Saeed 2008 carried out a postpartum contraceptive counselling and leaflet provision trial at the Department of Obstetrics and Gynaecology, Shifa International Hospital, Islamabad, Pakistan. Six hundred and forty-eight women were enrolled in the study, of which 48 were lost to follow-up. After delivery, the women were randomised into control and intervention groups by the use of four randomisation charts. Each woman in the intervention group received 20 minutes of informal contraceptive counselling along with her husband or a close relative, and a simple one-page leaflet on contraceptive methods was given at the time of discharge. Control group women were discharged without a counselling session or leaflets and both groups were asked return for follow-up at 8 to 12 weeks postnatal.

Schunmann 2006 conducted a randomised controlled trial of specialist contraceptive counselling and enhanced contraceptive provision after termination of pregnancy (TOP) in a hospital in Edinburgh. The intervention group $(n=316)$ received an in-depth interview on demographic details and a full reproductive history before termination, in addition to contraceptive discussions at the initial consultation with standard care provided $(n=297)$. The intervention group also received three months' supply of oral contraceptive pills or firm arrangements for insertion of IUD/IUS at a local family planning clinic for medical TOP patients, whereas the standard care is one month's supply of pills and referral to a local family planning clinic. Insertion of IUD/IUS was offered to both control and intervention groups, but only women in the intervention group were offered implants.

Smith 2002 examined the effects of contraceptive counselling at an antenatal clinic appointment that took place between 24 and 36 weeks of pregnancy. The randomised controlled study was carried 
out in three different locations across three continents: People's Republic of China (Shanghai), South Africa (Cape Town) and Scotland (Edinburgh). Antenatal clinic sessions were randomised on a weekly basis in Edinburgh and Cape Town, and on a daily basis in Shanghai. A total of 771 participants received expert contraceptive advice and 886 controls received standard care. Although it was cross-national study, data and analysis were reported by individual site.

Soliman 1999 investigated the impact of antenatal counselling on knowledge and practice of contraception among a postnatal cohort at the maternity hospital at the University of Mansoura. The randomised controlled trial consists of 200 women participants who were randomly assigned to the control and intervention group. Antenatal counselling sessions were provided for the women and their husbands using the GATHER (Greet, Ask, Tell, Help, Explain, Return) technique.

\section{Excluded studies}

Of the relevant studies we retrieved, we excluded 31 studies with reasons. Some of the reasons for exclusion were:

- no IUD outcome reported and no specific data on IUD available from the study's primary author whether use or continuation;

- participants fell outside of the inclusion criteria, e.g. males;

- no comparison group with the intervention group, or crosssectional study with no baseline;

- participants were recruited on the basis of request for IUD insertion.

Excluded studies may have more than one reason for exclusion. We excluded the majority of the excluded studies due to lack of data on IUD.

\section{Risk of bias in included studies}

The 'Risk of bias' summary has been illustrated in Figure 1. 
Figure I. 'Risk of bias' summary: review authors' judgements about each risk of bias item for each included study.

\begin{tabular}{|c|c|c|c|c|c|c|c|}
\hline & 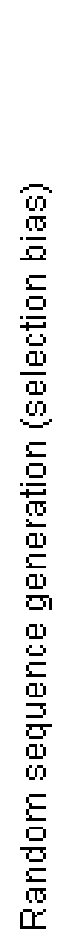 & 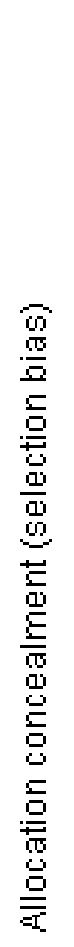 & 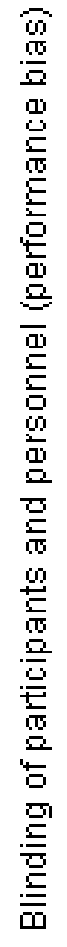 & 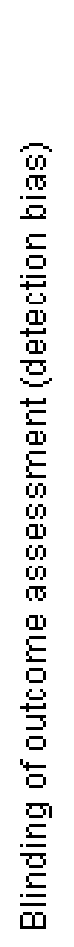 & 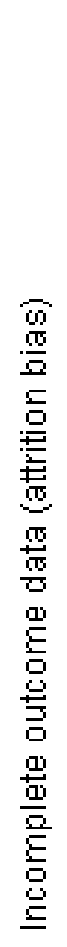 & 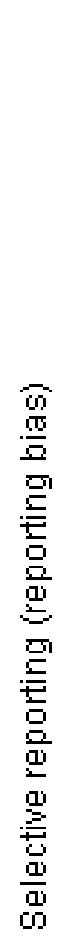 & 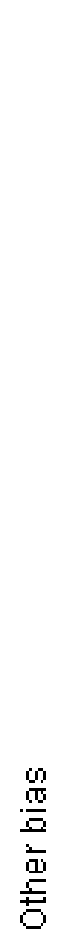 \\
\hline Bashour 2008 & + & + & $?$ & + & + & + & $?$ \\
\hline Douthwaite 2005 & & 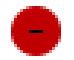 & $?$ & - & + & + & + \\
\hline Ferreira 2010 & + & + & $?$ & + & 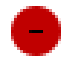 & C & + \\
\hline Jahanfar 2005 & + & $?$ & - & - & + & $?$ & $?$ \\
\hline Kambo 1994 & + & - & $?$ & $?$ & & $?$ & + \\
\hline Saeed 2008 & + & + & $?$ & + & $?$ & & ? \\
\hline Schunmann 2006 & + & $?$ & $?$ & + & + & + & $?$ \\
\hline Smith 2002 & + & $?$ & $?$ & $?$ & & $?$ & $?$ \\
\hline Soliman 1999 & & $?$ & $?$ & $?$ & + & $?$ & \\
\hline
\end{tabular}




\section{Allocation}

All studies were randomised except one, Douthwaite 2005, which attempted matching between the control and intervention groups. Information on sequence generation was provided for all randomised studies, except one trial (Soliman 1999) which did not provide details on the randomisation process. Four trials (Bashour 2008; Ferreira 2010; Saeed 2008; Schunmann 2006) had adequate concealment of allocation.

\section{Blinding}

The blinding of assignment was not stated in most trials and blinding was not possible due to the nature of the interventions. The outcome assessors were blind to the allocation in four studies (Bashour 2008; Ferreira 2010; Saeed 2008; Schunmann 2006). Two of the studies (Douthwaite 2005; Jahanfar 2005) were evaluated by the supervisors who trained the personnel. It was not clear whether the outcome assessors were blinded in three of the studies (Kambo 1994; Smith 2002; Soliman 1999).

\section{Incomplete outcome data}

Losses to follow-up were high(20\% or greater) in three of the studies (Ferreira 2010; Kambo 1994; Smith 2002). All studies specified information about losses by study group except one ( Saeed 2008).

\section{Selective reporting}

All included studies clearly defined their main objectives and interventions. One study (Saeed 2008) did not report knowledge of contraception postintervention, although it was one of the aims of the study. Ferreira 2010 provided results based on an intention-totreat analysis and no comparison was made between $45 \%$ of the control group who discontinued the education group counselling and those who did not. The study concluded that individualised contraceptive counselling had greater acceptability compared to the control group $(98.4 \%$ compared to $70.6 \%)$ although almost half of those in the control group discontinued.

\section{Other potential sources of bias}

Power and sample size calculations were not reported in three of the studies (Bashour 2008; Jahanfar 2005; Saeed 2008). There was no information on the "routine care" that the control group received in Soliman 1999.

\section{Effects of interventions}

See: Summary of findings for the main comparison Community-based contraceptive counselling; Summary of findings 2 Antenatal contraceptive counselling for postpartum contraceptive use; Summary of findings 3 Postnatal contraceptive counselling and information leaflet prior to discharge; Summary of findings 4 Contraceptive counselling during postnatal home visits; Summary of findings 5 Enhanced contraceptive counselling and provision postabortion

Overall, the studies included fell into three types of interventions: community-based contraceptive provision, interventions for postpartum contraception, and interventions for postabortion contraception. Due to differences in the interventions and participants, we did not combine all the studies in a meta-analysis. We performed subgroup analyses for each type of intervention and presented pooled data where appropriate. We were unable to include most of the secondary outcomes in the analysis due to lack of data.

\section{Community-based counselling and referral}

Three studies (Douthwaite 2005; Jahanfar 2005; Kambo 1994) with an aggregated sample size of 6624 (intervention $=4246$, control $=1978$ ) reported the impact of contraceptive counselling and referral by trained community workers on uptake of modern contraceptives including intrauterine device (IUD). A greater increase in uptake of IUD for the intervention groups was observed (Peto odds ratio (OR) 1.56; 95\% confidence interval (CI) 1.04 to 2.33 and Peto OR 5.08; 95\% CI 2.34 to 11.03 ) in Douthwaite 2005 and Kambo 1994, respectively; and zero uptake of IUD was reported for both intervention and control group in Jahanfar 2005 (Figure 2). When we pooled data from the studies we detected statistically significant heterogeneity $\left(\mathrm{Chi}^{2}=7.05, \mathrm{df}=1\right.$, $\left.\mathrm{P}=0.008, \mathrm{I}^{2}=86 \%\right)$. This high heterogeneity was possibly due to a large study effect shown in Kambo 1994, however we were not able to perform subgroup analysis given the small number of studies. 
Figure 2. Forest plot of comparison: I Effectiveness of community-based family planning programme: community workers versus control, outcome: I.I Uptake of IUD.

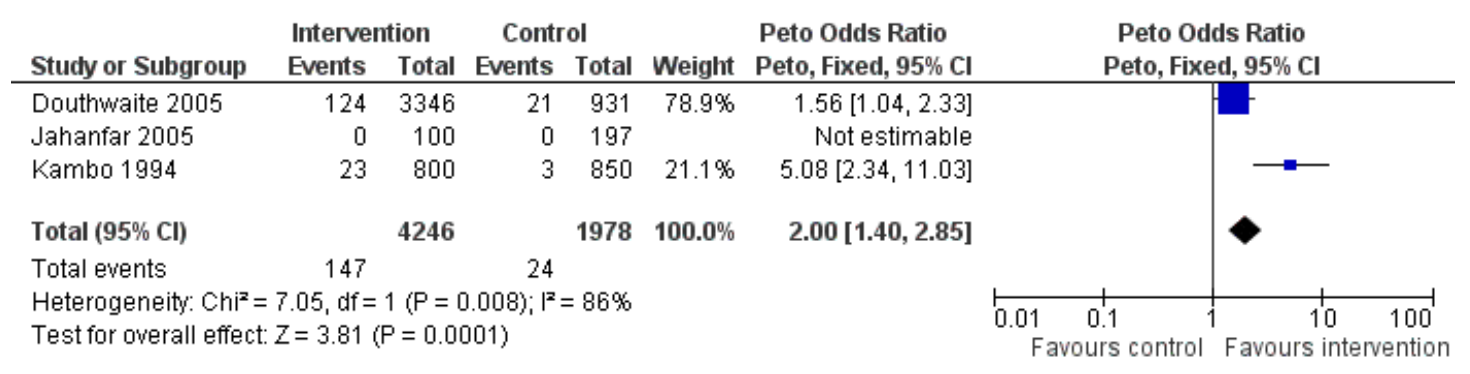

Only one study assessed knowledge of IUD as an outcome. Kambo 1994 reported a significantly greater increase in knowledge about the method for the intervention group compared to control group (Mantel-Haenszel (M-H) OR 39.00; 95\% CI 15.91 to 95.62) (Figure 3). The study also reported an increase in knowledge in terms of availability and where to obtain the IUD in the intervention group compared to the control group (M-H OR 2.68; $95 \%$ CI 2.19 to 3.27).

Figure 3. Forest plot of comparison: I Effectiveness of community-based family planning programme: community workers versus control, outcome: I.2 Knowledge of IUD.

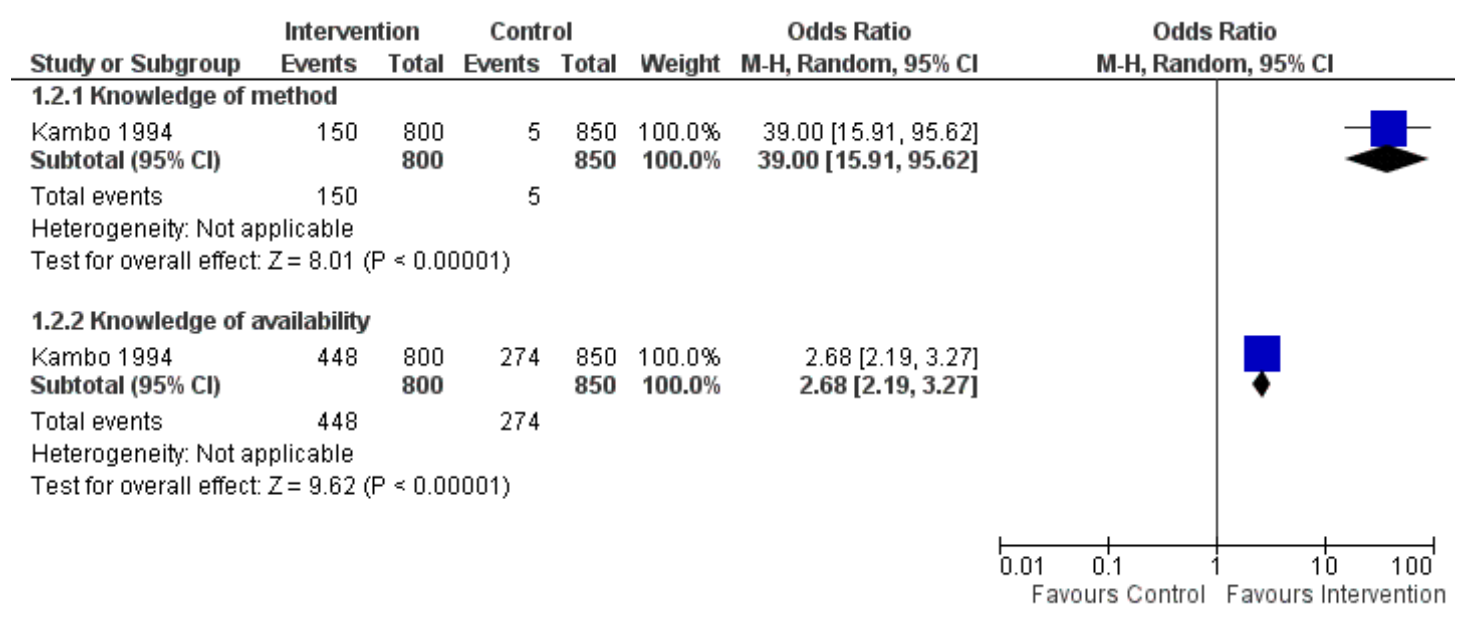

\section{Counselling for postpartum contraception}

Four studies evaluated contraceptive counselling to improve uptake of postpartum contraception. Two of the studies (Bashour 2008; Saeed 2008) were randomised controlled trials on postnatal contraceptive counselling, and Smith 2002 and Soliman 1999 were on antenatal contraceptive counselling.

\section{Postnatal counselling}

Two studies assessed the impact of postnatal contraceptive counselling on postpartum contraceptive use. Due to significant differ- 
ences between the studies $\left(\mathrm{Chi}^{2}=11.29, \mathrm{df}=1, \mathrm{P}=0.0008, \mathrm{I}^{2}\right.$ $=91.1 \%$ ), we did not pool data. Saeed 2008, a randomised controlled trial on provision of contraceptive counselling with husband or close relative and an educational leaflet priori to discharge, showed a greater increase in IUD uptake among the intervention group compare to the control (Peto OR 5.73; 95\% CI 3.59 to 9.15). Bashour 2008, a trial of postnatal contraceptive discussion at home visits, also showed an increase in IUD uptake among the intervention group compared to the control (Peto OR 1.96; 95\% CI 0.90 to 2.85), however this increase was not statistically significant (Figure 4).

Figure 4. Forest plot of comparison: 2 Effectiveness of contraceptive counselling provision among postpartum population: postnatal counselling versus control, outcome: 2.I Uptake of IUD.

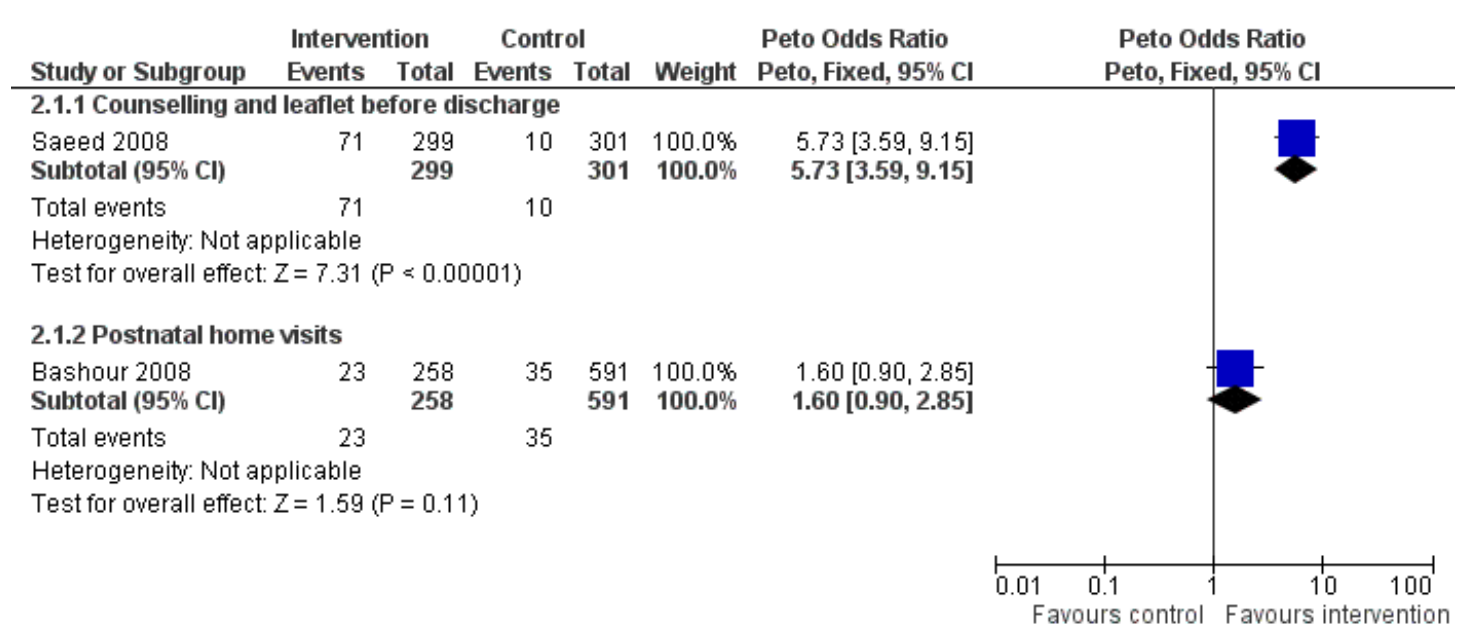

\section{Antenatal counselling}

The pooled data with an aggregated sample size of 1491 (intervention $=717$, control $=774$ ) indicated a greater increase in IUD uptake at 12 weeks postpartum for those who received antenatal contraceptive counselling compared to those in the control group (Peto OR 2.33; 95\% CI 1.39 to 3.91)(Figure 5). We noted a medium level of heterogeneity $\left(\mathrm{Chi}^{2}=8.09, \mathrm{df}=3, \mathrm{P}=0.04, \mathrm{I}^{2}=\right.$ $63 \%$ ) and subgroup analysis showed that only among those with

a normal pregnancy in Soliman 1999 was there a statistically significant increase in use in the intervention group compared to the control (Peto OR 5.00; 95\% CI 2.34 to 12.01). However, in the Smith 2002 study, there were differences in standard care between the sites: in Shanghai and Cape Town standard care included a postpartum contraception discussion while standard care in Edinburgh involved no formal discussion of postpartum contraception during the antenatal period. 
Figure 5. Forest plot of comparison: 3 Effectiveness of contraceptive counselling provision among postpartum population (short-term): antenatal counselling versus control, outcome: 3.I Uptake of IUD.

\begin{tabular}{|c|c|c|c|c|c|c|c|}
\hline \multirow{2}{*}{$\frac{\text { Study or Subgroup }}{\text { 3.1.1 Edinburgh }}$} & \multicolumn{2}{|c|}{ Intervention } & \multicolumn{2}{|c|}{ Control } & Weight & $\begin{array}{l}\text { Peto Odds Ratio } \\
\text { Peto, Fixed, } 95 \% \mathrm{Cl}\end{array}$ & $\begin{array}{c}\text { Peto Odds Ratio } \\
\text { Peto, Fixed, 95\% Cl }\end{array}$ \\
\hline & & & & & & & \\
\hline $\begin{array}{l}\text { Smith } 2002 \\
\text { Subtotal }(95 \% \mathrm{Cl})\end{array}$ & 5 & $\begin{array}{l}171 \\
171\end{array}$ & 5 & $\begin{array}{l}214 \\
214\end{array}$ & $\begin{array}{l}16.7 \% \\
16.7 \%\end{array}$ & $\begin{array}{l}1.26[0.36,4.45] \\
1.26[0.36,4.45]\end{array}$ & \\
\hline $\begin{array}{l}\text { Total events } \\
\text { Heterogeneity: Not a } \\
\text { Test for overall effect }\end{array}$ & $\begin{array}{l}5 \\
\text { plicable } \\
Z=0.36\end{array}$ & $=0.72$ & 5 & & & & \\
\hline 3.1.2 Shanghai & & & & & & & \\
\hline $\begin{array}{l}\text { Smith } 2002 \\
\text { Subtotal (95\% Cl) }\end{array}$ & 7 & $\begin{array}{l}254 \\
254\end{array}$ & 8 & $\begin{array}{l}263 \\
263\end{array}$ & $\begin{array}{l}25.3 \% \\
25.3 \%\end{array}$ & $\begin{array}{r}0.90[0.32,2.52] \\
\mathbf{0 . 9 0}[0.32,2.52]\end{array}$ & \\
\hline $\begin{array}{l}\text { Total events } \\
\text { Heterogeneity: Not a } \\
\text { Test for overall effect }\end{array}$ & $\begin{array}{r}7 \\
\text { plicable } \\
Z=0.19 \text { ( }\end{array}$ & $=0.85$ & 8 & & & & \\
\hline 3.1.3 Cape Town & & & & & & & \\
\hline $\begin{array}{l}\text { Smith } 2002 \\
\text { Subtotal }(95 \% \mathrm{Cl})\end{array}$ & 0 & $\begin{array}{l}192 \\
192\end{array}$ & 0 & $\begin{array}{l}197 \\
197\end{array}$ & & $\begin{array}{l}\text { Not estimable } \\
\text { Not estimable }\end{array}$ & \\
\hline $\begin{array}{l}\text { Total events } \\
\text { Heterogeneity: Not a } \\
\text { Test for overall effect }\end{array}$ & $\begin{array}{l}0 \\
\text { plicable } \\
\text { Not appli }\end{array}$ & able & 0 & & & & \\
\hline 3.1.4 Mansoura & & & & & & & \\
\hline $\begin{array}{l}\text { Soliman } 1999 \\
\text { Subtotal }(\mathbf{9 5 \%} \mathrm{Cl})\end{array}$ & 33 & $\begin{array}{l}100 \\
100\end{array}$ & 9 & $\begin{array}{l}100 \\
100\end{array}$ & $\begin{array}{l}57.9 \% \\
57.9 \%\end{array}$ & $\begin{array}{r}4.22[2.14,8.32] \\
4.22[2.14,8.32]\end{array}$ & \\
\hline $\begin{array}{l}\text { Total events } \\
\text { Heterogeneity: Not a } \\
\text { Test for overall effect }\end{array}$ & $\begin{array}{l}33 \\
\text { plicable } \\
Z=4.160\end{array}$ & $<0.00$ & $001)$ & & & & \\
\hline Total $(95 \% \mathrm{Cl})$ & & 717 & & 774 & $100.0 \%$ & $2.33[1.39,3.91]$ & \\
\hline Total events & 45 & & 22 & & & & \\
\hline $\begin{array}{l}\text { Heterogeneity: } \text { Chi }^{2}= \\
\text { Test for overall effect } \\
\text { Test for subqroup dif }\end{array}$ & $\begin{array}{l}7.12, \mathrm{df}= \\
Z=3.21 \\
\text { erences: }\end{array}$ & $\begin{array}{l}2(P=0 \\
=0.00 \\
h^{2}=7\end{array}$ & $\begin{array}{l}0.03) ;\left.\right|^{2}= \\
\text { 1) } \\
12, d f=2\end{array}$ & $\begin{array}{l}72 \% \\
2(P=\end{array}$ & $03)\left.\right|^{2}=$ & $71.9 \%$ & $\begin{array}{rr}0.01 & 0.1 \\
& \text { Favours }\end{array}$ \\
\hline
\end{tabular}

\section{Enhanced counselling for postabortion contraception}

Two trials (Ferreira 2010; Schunmann 2006) evaluated enhanced counselling and contraceptive provision for postabortion contraceptive uptake. The pooled data from the studies showed low heterogeneity $\left(\mathrm{Chi}^{2}\right.$ square $\left.=1.44, \mathrm{df}=1, \mathrm{P}=0.23, \mathrm{I}^{2}=30.7 \%\right)$ and the difference between intervention and control groups was not statistically significant. Schunmann 2006 showed an increase in IUD uptake among those who received enhanced counselling and service provision, however it was not statistically significant (Figure 6). In the aggregated data, differences between intervention and control groups were also not found to be statistically significant. It is important to note that both control and intervention groups received some form of contraceptive counselling for both the postabortion studies included, but in the intervention groups this was more intensive. The control group in Schunmann 2006 received contraceptive counselling before the abortion procedure and further discussion after the abortion. Similarly, the control group in Ferreira 2010 received group contraceptive counselling. 
Figure 6. Forest plot of comparison: 6 Effectiveness of family planning counselling among postabortion population, outcome: 6.I Uptake of IUD.

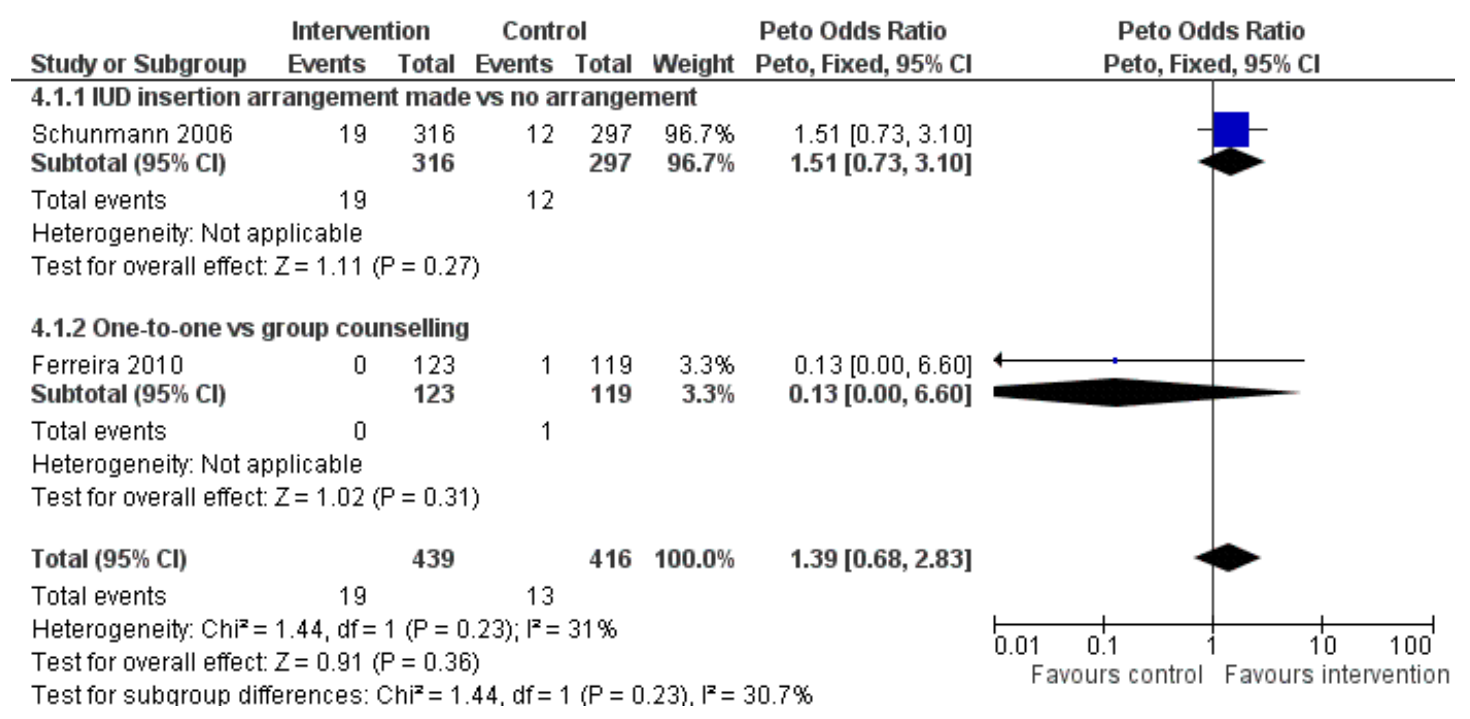




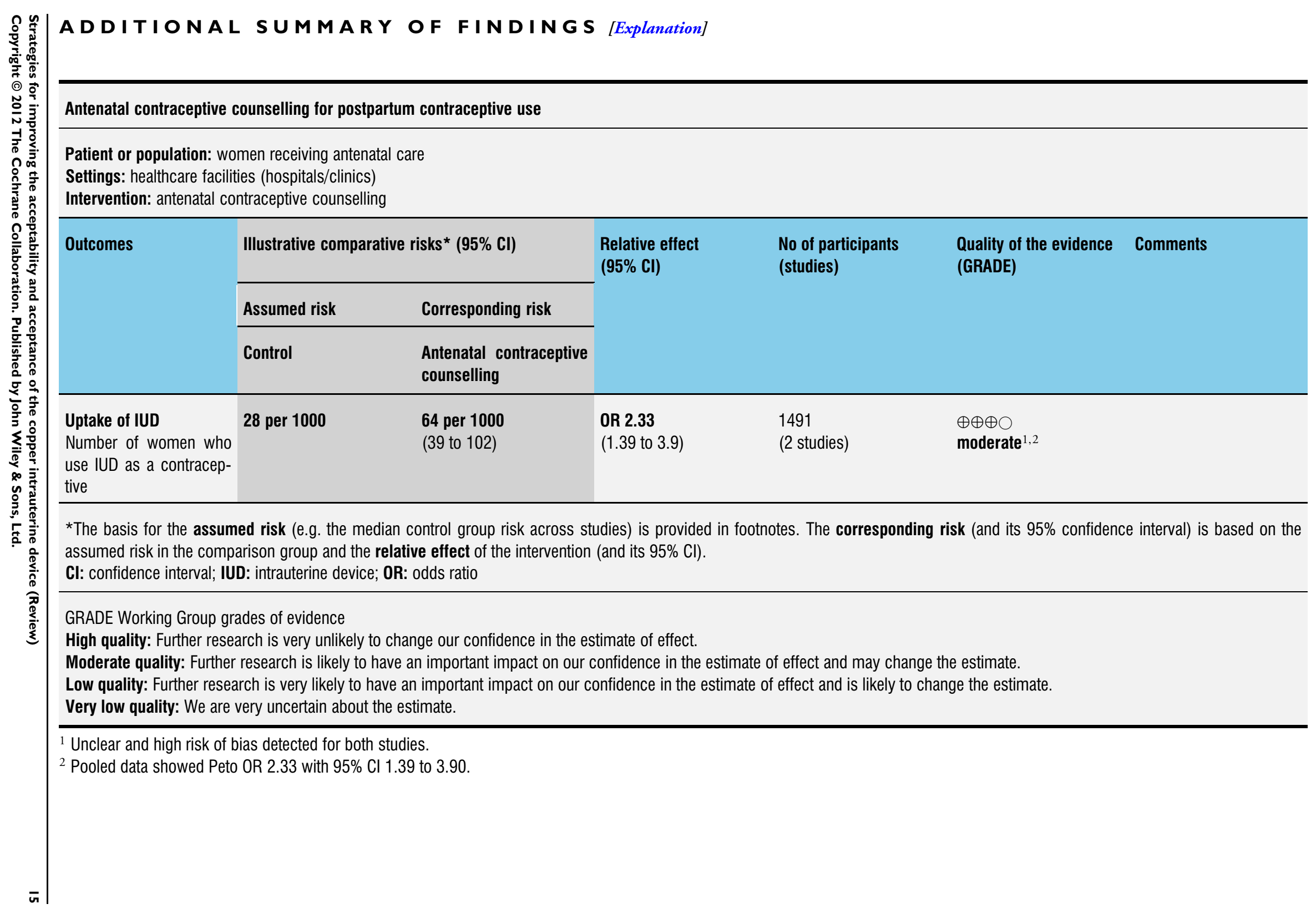


Postnatal contraceptive counselling and information leaflet prior to discharge

Patient or population: postpartum

Settings: healthcare facilities (hospital, maternity ward)

Intervention: postnatal contraceptive counselling and information leaflet prior to discharge from maternity ward

\begin{tabular}{|c|c|c|c|c|c|c|}
\hline \multirow[t]{3}{*}{ Outcomes } & \multicolumn{2}{|c|}{ Illustrative comparative risks* $(95 \%$ Cl) } & \multirow{3}{*}{$\begin{array}{l}\text { Relative effect } \\
\text { (95\% Cl) }\end{array}$} & \multirow{3}{*}{$\begin{array}{l}\text { No of participants } \\
\text { (studies) }\end{array}$} & \multirow{3}{*}{$\begin{array}{l}\text { Quality of the evidence } \\
\text { (GRADE) }\end{array}$} & \multirow[t]{3}{*}{ Comments } \\
\hline & Assumed risk & Corresponding risk & & & & \\
\hline & Control & $\begin{array}{l}\text { Postnatal contraceptive } \\
\text { counselling and infor- } \\
\text { mation leaflet prior to } \\
\text { discharge }\end{array}$ & & & & \\
\hline $\begin{array}{l}\text { Uptake of IUD } \\
\text { Number of women who } \\
\text { use IUD as a contracep- } \\
\text { tive }\end{array}$ & 33 per 1000 & $\begin{array}{l}165 \text { per } \mathbf{1 0 0 0} \\
\text { (110 to 239) }\end{array}$ & $\begin{array}{l}\text { OR } 5.73 \\
\text { (3.59 to } 9.15)\end{array}$ & $\begin{array}{l}600 \\
\text { (1 study) }\end{array}$ & $\begin{array}{l}\oplus \oplus \oplus \bigcirc \\
\text { moderate }\end{array}$ & \\
\hline
\end{tabular}

*The basis for the assumed risk (e.g. the median control group risk across studies) is provided in footnotes. The corresponding risk (and its $95 \%$ confidence interval) is based on the assumed risk in the comparison group and the relative effect of the intervention (and its $95 \% \mathrm{Cl}$.

CI: Confidence interval; IUD: intrauterine device; 0R: Odds ratio

GRADE Working Group grades of evidence

High quality: Further research is very unlikely to change our confidence in the estimate of effect.

Moderate quality: Further research is likely to have an important impact on our confidence in the estimate of effect and may change the estimate.

Low quality: Further research is very likely to have an important impact on our confidence in the estimate of effect and is likely to change the estimate.

Very low quality: We are very uncertain about the estimate.

${ }^{1}$ Outcome measures were not specified; knowledge mentioned in the aim and reported for the baseline but not reported postintervention.

${ }^{2}$ Large effect: uptake of IUD is large for the intervention group compared to the control. 
Postnatal home visits for postpartum care including contraception

Patient or population: postpartum

Settings: home

Intervention: postnatal home visits and contraceptive counselling during the visits

\begin{tabular}{|c|c|c|c|c|c|c|}
\hline \multirow[t]{3}{*}{ Outcomes } & \multicolumn{2}{|c|}{ Illustrative comparative risks* $(95 \% \mathrm{CI})$} & \multirow{3}{*}{$\begin{array}{l}\text { Relative effect } \\
(95 \% \mathrm{CI})\end{array}$} & \multirow{3}{*}{$\begin{array}{l}\text { No of participants } \\
\text { (studies) }\end{array}$} & \multirow{3}{*}{$\begin{array}{l}\text { Quality of the evidence } \\
\text { (GRADE) }\end{array}$} & \multirow[t]{3}{*}{ Comments } \\
\hline & Assumed risk & Corresponding risk & & & & \\
\hline & Control & Postnatal home visits & & & & \\
\hline $\begin{array}{l}\text { Uptake of IUD } \\
\text { Number of women who } \\
\text { use IUD as a contracep- } \\
\text { tive }\end{array}$ & 59 per 1000 & $\begin{array}{l}92 \text { per } 1000 \\
\text { (54 to } 152)\end{array}$ & $\begin{array}{l}\text { OR } 1.6 \\
\text { (0.9 to 2.85) }\end{array}$ & $\begin{array}{l}849 \\
\text { (1 study) }\end{array}$ & $\begin{array}{l}\oplus \oplus \bigcirc \bigcirc^{1} \\
\text { low }\end{array}$ & \\
\hline
\end{tabular}

*The basis for the assumed risk (e.g. the median control group risk across studies) is provided in footnotes. The corresponding risk (and its $95 \%$ confidence interval) is based on the assumed risk in the comparison group and the relative effect of the intervention (and its $95 \% \mathrm{Cl}$ ).

CI: confidence interval; IUD: intrauterine device; OR: odds ratio

GRADE Working Group grades of evidence

High quality: Further research is very unlikely to change our confidence in the estimate of effect.

Moderate quality: Further research is likely to have an important impact on our confidence in the estimate of effect and may change the estimate.

Low quality: Further research is very likely to have an important impact on our confidence in the estimate of effect and is likely to change the estimate.

Very low quality: We are very uncertain about the estimate.

${ }^{1}$ The study power calculation was performed to detect postpartum morbidity, namely haemorrhoids. Although contraceptive uptake was

one of the outcomes, all other (five) outcomes of the study were neonatal outcomes. 
Enhanced contraceptive counselling and provision for postabortion

Patient or population: postabortion

Settings: healthcare facilities

Intervention: enhanced contraceptive counselling and provision

\begin{tabular}{|c|c|c|c|c|c|c|}
\hline \multirow[t]{3}{*}{ Outcomes } & \multicolumn{2}{|c|}{ Illustrative comparative risks* (95\% CI) } & \multirow{3}{*}{$\begin{array}{l}\text { Relative effect } \\
(95 \% \mathrm{CI})\end{array}$} & \multirow{3}{*}{$\begin{array}{l}\text { No of participants } \\
\text { (studies) }\end{array}$} & \multirow{3}{*}{$\begin{array}{l}\text { Quality of the evidence } \\
\text { (GRADE) }\end{array}$} & \multirow[t]{3}{*}{ Comments } \\
\hline & Assumed risk & Corresponding risk & & & & \\
\hline & Control & $\begin{array}{l}\text { Enhanced contraceptive } \\
\text { counselling and provi- } \\
\text { sion }\end{array}$ & & & & \\
\hline $\begin{array}{l}\text { Uptake of IUD } \\
\text { Number of women using } \\
\text { IUD as a contraceptive }\end{array}$ & 31 per 1000 & $\begin{array}{l}\mathbf{4 3} \text { per } 1000 \\
(21 \text { to } 84)\end{array}$ & $\begin{array}{l}\text { OR } 1.39 \\
\text { (0.68 to 2.83) }\end{array}$ & $\begin{array}{l}855 \\
\text { (2 studies) }\end{array}$ & $\begin{array}{l}\oplus \oplus \bigcirc \bigcirc \\
\mathbf{l o w}^{1,2,3,4,5}\end{array}$ & \\
\hline
\end{tabular}

*The basis for the assumed risk (e.g. the median control group risk across studies) is provided in footnotes. The corresponding risk (and its $95 \%$ confidence interval) is based on the assumed risk in the comparison group and the relative effect of the intervention (and its $95 \% \mathrm{Cl}$ ).

CI: confidence interval; IUD: intrauterine device; OR: odds ratio

GRADE Working Group grades of evidence

High quality: Further research is very unlikely to change our confidence in the estimate of effect.

Moderate quality: Further research is likely to have an important impact on our confidence in the estimate of effect and may change the estimate.

Low quality: Further research is very likely to have an important impact on our confidence in the estimate of effect and is likely to change the estimate.

Very low quality: We are very uncertain about the estimate.

${ }^{1}$ Low and statistically not significant heterogeneity.

${ }^{2}$ One of the studies was a trial of one-to-one counselling versus group counselling; also another study recruited participants specifically from low-income group.

${ }^{3}$ One of the studies includes no effect with $95 \%$ confidence interval 0.00 to 6.60

${ }^{4} \mathrm{High}$ risk of bias for one of the studies.

5 The control group for one of the studies received group counselling and the discontinuation rate was $45 \%$, given that only one IUD

uptake for the control group and none among the intervention group, the results may be affected by the high discontinuation rate. 


\section{DISCUSSION}

\section{Summary of main results}

Three main types of interventions identified were: communitybased contraceptive counselling and referral, post- and antenatal contraceptive counselling, and enhanced postabortion contraceptive counselling. The community-based provision of contraceptive counselling studies provided evidence for an increase in intrauterine device (IUD) use among the intervention groups compared to the control groups.

Perinatal interventions evaluating both post- and antenatal counselling in healthcare settings led to an increase in uptake of the IUD; however postnatal home visits did not demonstrate statistically significant increases in uptake of the IUD postpartum, compared to usual care.

Intensive contraceptive counselling postabortion compared with standard care did not result in a statistically significant increase in IUD uptake; however the strength of evidence in this area was low. None of the studies included compared contraceptive counselling around the time of termination of pregnancy with no contraceptive counselling. The studies included in the review were comparing intensive one-to-one contraceptive counselling and enhanced provision to group contraceptive counselling or less intensive contraceptive counselling, and they did not show significantly improved uptake of the copper IUD. Therefore, we cannot conclude that enhanced contraceptive counselling postabortion is not an effective intervention for improving use of the copper IUD per se as we were not able to compare it with no provision.

Only one study, on community-based distribution and counselling, evaluated changes in knowledge by method, and the results showed a substantial increase in knowledge, both in terms of understanding the IUD and knowing where to access the method.

\section{Overall completeness and applicability of evidence}

We restricted studies which did not report use of the IUD as an outcome; a few of the studies excluded reported uptake of highly effective or effective contraceptives but did not distinguish this by specific method. We contacted primary authors for clarification and requested additional data for those with no specific IUD data reported.

\section{Quality of the evidence}

We used the GRADE approach to evaluate the quality of evidence (GRADE Working Group 2004). The dimensions considered are: study design and risk of bias, study limitation (risk of bias), inconsistency of results, indirectness of evidence, imprecision, publication bias, large or very large effect, and plausible confounding factors that would change the effect. The assessment was grouped based on the data for analysis. We found the quality of evidence for enhanced counselling and contraceptive provision for uptake of postabortion contraception to be low (Summary of findings 5).
We found the quality of evidence on contraceptive counselling and referral by community workers and antenatal contraceptive counselling to be moderate (Summary of findings for the main comparison; Summary of findings 2). We found the quality of evidence for postnatal contraceptive counselling prior to discharge and postnatal home visits for postpartum contraception to be low (Summary of findings 3; Summary of findings 4).

\section{Potential biases in the review process}

The quality of review might have been affected as no included studies were specifically aiming to increase acceptability and acceptance of the copper IUD (as opposed to contraception or reliable contraception in general). We found in the initial exploratory search that we would be unlikely to find studies specifically designed with an objective of increasing uptake of only the copper IUD. Therefore, we widened our search strategy to include all studies aiming to improve use of any type of contraception. Although we did not restrict our search to English language only, all our search engines are in English and generated very few articles or reports of studies that were not published in English.

\section{Agreements and disagreements with other studies or reviews}

We have found no previous studies or reviews specifically measuring uptake of the IUD. In terms of interventions for postpartum contraception, our findings were consistent with a Cochrane systematic review on education for contraceptive use by women after childbirth (Lopez 2010). The review focused on postnatal counselling only and concluded that contraceptive education may increase contraceptive use. Our analysis also showed an increase in uptake of the IUD in the intervention groups compared to the control groups for both postnatal and antenatal counselling. Our findings on enhanced contraceptive counselling and provision for postabortion contraception were also consistent with a previously published systematic review (Ferreira 2009). Ferreira 2009 reviewed the effect of contraceptive counselling on the use of family planning methods and found no differences between the intervention and control groups.

\section{AUTHORS, CONCLUSIONS}

\section{Implications for practice}

Contraceptive counselling and referral by trained communitybased workers led to more intrauterine device (IUD) use than no provision. However, the generalisability of these developing country studies to developed country settings may need further evaluation. Antenatal contraceptive counselling was effective in increasing uptake of the copper IUD for postpartum contraception. 
Postnatal couple contraceptive counselling and information leaflet provision prior to discharge also showed an increase in uptake of the IUD compared to those discharged without this intervention.

\section{Implications for research}

None of the studies included had the specific aim of improving uptake of the copper IUD, though uptake of contraceptives was sometimes reported by method. Secondary outcomes of our review, continuation rates, were rarely reported; the few studies that reported contraceptive use in the long-term had no individual follow-up but instead reported cohort effect. Most of the randomised controlled trials did not report power and sample size calculations, or allocations to intervention and control groups. Better documentation and reporting are needed on the research design and long-term impact of interventions for long-acting contraceptives.

\section{REF ER E N C E S}

\section{References to studies included in this review}

\section{Bashour 2008 \{published data only\}}

Bashour NH, Kharouf MH, Abdulsalam AS, Asmar KE, Tabbaa MA, Cheikha SA. Effect of postnatal home visits on maternal/infant outcomes in Syria: a randomized controlled trial. Public Health Nursing 2008;25(2):115-25.

Douthwaite 2005 \{published data only\}

Douthwaite M, Ward P. Increasing contraceptive use in rural Pakistan: an evaluation of the Lady Health Worker programme. Health Policy and Planning 2005;20(2): $117-23$.

Ferreira 2010 \{published data only\}

Ferreira ALCG, Souza AI, Lima RA, Braga C. Choices on contraceptive methods in post-abortion family planning clinic in the northeast Brazil. Reproductive Health, BioMed Central 2010;7:5.

* Ferreira ALCG, Souza AI, Pessoa RE, Braga C. The effectiveness of contraceptive counseling for women in the postabortion period: an intervention study. Contraception 2011;84(4):377-83.

\section{Jahanfar 2005 \{published data only\}}

Jahanfar S, Ghodsi M, Shahpoorian F, Jamshidi R. Community-based distribution and contraceptive usage in Iran. Journal of Family Planning and Reproductive Health Care 2005;31(3):194-7.

Kambo 1994 \{published data only\} Kambo IP, Gupa RN, Kundu AS, Dhillion BS, Saxena HM, Saxena BN. Use of traditional medical practitioners to deliver family planning services in Uttar Predesh. Studies in Family Planning 1994;25(1):32-40.

Saeed 2008 \{published data only\} Saeed GA, Fakhar S, Rahim F, Tabassum S. Change in trend of contraceptive uptake - effect of educational leaflets and counseling. Contraception 2008;77:377-81.

\section{ACKNOWLEDGEMENTS}

We are very grateful to all the investigators who provided additional information, especially to Dr John Stanback of Family Health International, for taking time to search and send additional unpublished research summaries of interest. We thank Helen Atherton for her help with producing the GradePro 'Summary of findings' table.
Schunmann 2006 \{published and unpublished data\} Shunmann C, Glasier A. Specialist contraceptive counselling and provision after termination of pregnancy improves uptake of long-acting methods but does not prevent repeat abortion: a randomized trial. Human Reproduction 2006;21 (9):2296-303.

Smith 2002 \{published data only\} Smith KB, Spuy ZM, Cheng L, Elton R, Glasier AF. Is postpartum contraceptive advice given antenatally of value?. Contraception 2002;65:237-43.

Soliman 1999 \{published data only\} Soliman MH. Impact of antenatal counselling on couples' knowledge and practice of contraception in Mansoura, Egypt. Eastern Mediterranean Health Journal 1999;5(5): $1002-13$.

\section{References to studies excluded from this review}

Bender 2004 \{published and unpublished data\} Bender SS, Geirsson RT. Effectiveness of preabortion counseling on postabortion contraceptive use. Contraception 2004;69:481-7.

Bianchi-Demicheli 2003 \{published data only\} Bianchi-Demicheli F, Perrin E, Bianchi PG, Dumont P, Lüdicke F, Campana A. Contraceptive practice before and after termination of pregnancy: a prospective study. Contraception 2003;67:107-13.

Boise 2003 \{published data only\} Boise R, Petersen R, Curtis KM, Aalborg A, Yoshida CK, Cabral R, et al.Reproductive health counseling at pregnancy testing: a pilot study. Contraception 2003;68:377-83.

\section{Bolam 1998 \{published data only\}} Bolam A, Manandhar DS, Shrestha P, Ellis M, Costello AM. The effects of postnatal health education for mothers on infant care and family planning practices in Nepal: a randomised controlled trial. BMJ 1998;316:805-11. 
Daniel 2008 \{published data only\}

Daniel EE, Masilamani R, Rahman M. The effect of community-based reproductive health communication interventions on contraceptive use among young married couples in Bihar, India. International Family Planning Perspectives 2008;34(4):189-97.

El-Tagy 2003 \{published data only\} El-Tagy A, Sakr E, Sokal DC, Issa AH. Safety and acceptability of post-abortal IUD insertion and the importance of counseling. Contraception 2003;67:229-34.

Goodman 2008 \{published data only\}

Goodmand S, Hendlish SK, Benedict C, Reeves MF, Pera-Floyd M, Foster-Rosales A. Increasing intrauterine contraception use by reducing barriers to post-abortal and interval insertion. Contraception 2008;78:136-42.

\section{Ha 2003 \{published data only\}}

Ha BTT, Jayasuriya R, Owen N. Male involvement in family planning in rural Vietnam: an application of the Transtheoretical Model. Health Education Research 2003;18 (2):171-80.

Ha 2005 \{published data only\}

* Ha BTT, Jayasuriya R, Owen N. Increasing male involvement in family planning decision making: trial of a social-cognitive intervention in rural Vietnam. Health Education Research 2005;20(5):548-56.

Hubacher 2006 \{published data only\} Hubacher D, Vilchez R, Gmach R, Jarquin C, Medrano J, Gadea A, et al.The impact of clinician education on IUD uptake, knowledge and attitudes: results of a randomized trial. Contraception 2006;73:628-33.

Johnson 2002 \{published data only\} Johnson BR, Singatsho N, Farr SL, Chipato T. Reducing unplanned pregnancy and abortion in Zimbabwe through postabortion contraception. Studies in Family Planning 2002;33(2):195-202.

Langston 2010 \{published data only\} Langston AM, Rosario L, Westhoff CL. Structured contraceptive counseling - a randomized controlled trial. Patient Education and Counseling 2010;81:362-7.

\section{Lee 2011 \{published data only\}}

Lee AJ, Tsai JL, Tsou TS, Chen MC. Effectiveness of a theory-based postpartum sexual health education program on women's contraceptive use: a randomized controlled trial. Contraception 2011;84:48-56.

Lou 2004 \{published data only\}

Lou C, Wang B, Shen Y, Gao E. Effects of a communitybased sex education and reproductive health service program on contraceptive use of unmarried youths in Shanghai. Journal of Adolescent Health 2004;34:433-40.

Luck 2000 \{published data only\} Luck M, Jarju E, Nell MD, George MO. Mobilizing demand for contraception in rural Gambia. Studies in Family Planning 2000;31(4):325-35.
Masch 2008 \{published data only\}

Masch R, Cabrera I, Abder R, Baecher L, Cremer M, Gokhale A, et al.The effect of consolidation of abortion services on patient outcomes. Contraception 2008;77:60-3.

McCarraher 2010 \{published data only\} McCarraher DR, Chen-Mok M, Oronoz AS, BritoAnderson S, Grey T, Tuckers H, et al.Meeting the needs of the adolescent post-abortion care patients in the Dominican Republic. Journal of Biosocial Science 2010;42:493-509.

Nac. ar 2003 \{published data only\}

Nac, ar M, Öztürk A, Öztürk Y. The effect of family planning education given during postpartum period on the use of contraceptive methods. Erciyes Medical Journal 2003; 25(3): 122-30.

\section{Nobili 2006 \{published data only\}}

Nobili MP, Piergrossi S, Brusati V, Moja EA. The effect of patient-centered contraceptive counseling in women who undergo a voluntary termination of pregnancy. Patient Education and Counseling 2006;65:361-8.

Ortayli 2001 \{published data only\} Ortayli N, Bulut A, Nalbant H. The effectiveness of preabortion contraception counseling. International Journal of Gynecology \& Obsterics 2001;74:281-5.

\section{PARTNERS Project 2000 \{published data only\}}

Kraft JM, Harvey SM, Thorburn S, Handerson JT, Posner SF, Galavotti C. Interviewing with couples: assessing contraceptive outcomes in a randomized pregnancy and HIV/STD risk reduction intervention trial. Women's Health Issues 2007;17:52-60.

Ponce 2000 \{published data only\} Ponce ECL, Sloan NL, Winikoff B, Langer A, Coggins C, Heimburger A, et al.The power of information and contraceptive choice in a family planning setting in Mexico. Sexually Transmitted Infections 2000;76:277-81.

Postlethwaite 2007 \{published data only\} Postlethwaite D, Shaber R, Mancuso, V, Flores J, Armstrong MA. Intrauterine contraception: evaluation of clinician practice patterns in Kaiser Permanente North California. Contraception 2007;75:177-84.

Rasch 2004 \{published data only\} Rasch V, Massawe S, Yambesi F, Bergstrom S. Acceptance of contraceptive among women who had an unsafe abortion in Dar es Salaam. Tropical Medicine and International Health 2004;9(3):399-405.

Rasch V, Yambesi F, Massaew S. Medium and long-term adherence to postabortion contraception among women having experienced abortion in Dar es Salaam, Tanzania. BMC Pregnancy and Childbirth 2008;8:32.

Rose 2010 \{published data only\}

Rose SB, Lawton BA, Brown SA. Uptake and adherence to long-acting reversible contraception post-abortion. Contraception 2010;82:345-53.

Sääv 2007 \{published data only\}

Sääv I, Aronsson A, Marions L, Stephansson O, GemzellDanielsson K. Cervical priming with sublingual misoprostol 
prior to insertion of an intrauterine device in nulliparous women: a randomized controlled trial. Human Reproduction 2007;22(10):2647-52.

Shrestha 2002 \{published data only\}

Shrestha S. Increasing contraceptive acceptance through empowerment of female community health volunteers in rural Nepal. Journal of Health, Population and Nutrition 2002;20(2):156-65.

Shrewood-Fabre 2002 \{published data only\}

Sherwood-Fabre L, Goldberg H, Bodrova V. The impact of an integrated family planning program in Russia. Evaluation Review 2002;26:190-212.

Stevens 1992 \{published data only\}

Stevens JR, Stevens CM. Introductory small cash incentives to promote child spacing in India. Studies in Family Planning 1992;23(3):171-86.

Thompson 2006 \{published data only\}

Thompson ME, Harutyunyan TL. Contraceptive practices in Armenia: panel evaluation of an Information-EducationCommunication campaign. Social Sciences \& Medicine 2006;63:2770-83.

Yassin 2005 \{published data only\}

Yassin AS, Cordwell D. Does dedicated pre-abortion contraception counselling help to improve post-abortion contraception uptake?. Journal of Family Planning and Reproductive Health Care 2005;31(2):115-6.

Zhu 2009 \{published data only\}

Zhu JL, Zhang W, Cheng Y, Xu J, Xu X, Gibson D, et al.Impact of post-abortion family planning services on contraceptive use and abortion rate among young women in China: a cluster randomised trial. European Journal of Contraception and Reproductive Health Care 2009;14(1): 46-54.

\section{References to ongoing studies}

Dulli 2010 \{published data only\}

Dulli LS, Sortijas S, Ngabo F. Postpartum Family Planning Service Through Enhanced Family Planning in Immunization Services (PPFP-IZ). ClinicalTrials.gov 2010.

Norman 2010 \{published data only\}

Norman WV. Better contraceptive choices for marginalized women: a randomised controlled trial comparing immediate or interval insertion of intrauterine contraception after second trimester abortion. WHO International Clinical Trials Registry 2010.

\section{Additional references}

\section{Belfield 2009}

Belfield T. Principles of contraceptive care: choice, acceptability and access. Best Practice \& Research. Clinical Obstetrics \& Gynaecology 2009;23(2):177-85.

\section{Campbell 2006}

Campbell M. Consumer behaviour and contraceptive decisions: resolving a decades-long puzzle. Journal of Family Planning and Reproductive Health Care 2006;32(4):241-4.

\section{Chan 2005}

Chan A, Altman DG. Identifying outcome reporting bias in randomised trials on PubMed: review of publications and survey of authors. BMJ 2005;330(7494):753.

\section{Cheng 2008}

Cheng L, Gülmezoglu AM, Piaggio GGP, Ezcurra EE, Van Look PPFA. Interventions for emergency contraception. Cochrane Database of Systematic Reviews 2008, Issue 2. [DOI: 10.1002/14651858.CD001324.pub3]

\section{Davie 1996}

Davie JE, Walling MR, Mansour DJA, Bromham D, Kishen $\mathrm{M}$, Fowler P. Impact of patient counseling on acceptance of the levonorgestrel implant contraceptive in the United Kingdom. Clinical Therapeutics 1996;18(1):150-9.

\section{Ferreira 2009}

Ferreira ALCG, Lemos A, Figueiroa JN, deSouza AI. Effectiveness of contraceptive counselling of women following an abortion: a systematic review and metaanalysis. European Journal of Contraception and Reproductive Health Care 2009;14(1):1-9.

\section{Frost 2008}

Frost JJ, Darroch JE. Factors associated with contraceptive choice and inconsistent method use, United States, 2004. Perspectives on Sexual and Reproductive Health 2008;40(2): 94-104.

\section{GRADE Working Group 2004}

Grades of Recommendation, Assessment, Development, and Evaluation (GRADE) Working Group. Grading quality of evidence and strength of recommendations. BMJ 2004; 328:1490-7.

Haimovich 2009

Haimovich S. Profile of long-acting reversible contraception users in Europe. European Journal of Contraception and Reproductive Health Care 2009;14:187-95.

\section{Halpern 2006}

Halpern V, Grimes DA, Lopez L, Gallo MF. Strategies to improve adherence and acceptability of hormonal methods for contraception. Cochrane Database of Systematic Reviews 2006, Issue 1. [DOI: 10.1002/ 14651858.CD004317.pub2]

Higgins 2009

Higgins JPT, Green S (editors). Cochrane Handbook for Systematic Reviews of Interventions Version 5.0.2 [updated September 2009]. The Cochrane Collaboration, 2009. Available from www.cochrane-handbook.org. The Cochrane Collaboration.

\section{Kirkham 2010}

Kirkham JJ, Dwan KM, Altman DG, Gamble C, Dodd $\mathrm{S}$, Smyth R, et al.The impact of outcome reporting bias in randomised controlled trials on a cohort of systematic reviews. BMJ 2010;340:c365.

\section{Kost 2008}

Kost K, Singh S, Vaughan B, Trussell J, Bankole A. Estimates of contraceptive failure from the 2002 National Survey of Family Growth. Contraception 2008;77(1):10-21. 


\section{Lader 2009}

Lader D. Opinions Survey Report No. 41: Contraception and Sexual Heath, 2008/09. Office for National Statistics (ONS), 2009.

\section{Lopez 2010}

Lopez LM, Hiller JE, Grimes DA. Education for contraceptive use by women after childbirth. Cochrane Database of Systematic Reviews 2010, Issue 1. [DOI: 10.1002/14651858.CD001863.pub2]

\section{Mansour 2010}

Mansour D, Inki P, Gemzell-Danielsson K. Efficacy of contraceptive methods: a review of the literature. European Journal of Contraception and Reproductive Health Care 2010 15(1):4-16.

\section{Oddens 1997}

Oddens BJ. Determinants of contraceptive use among women of reproductive age in Great Britain and Germany II: Psychological factors. Journal of Biosocial Science 1997; 29(04):437-70.

\section{RevMan 2011}

The Nordic Cochrane Centre, The Cochrane Collaboration. Review Manager (RevMan). 5.1. Copenhagen: The Nordic Cochrane Centre, The Cochrane Collaboration, 2011.

\section{Sivin 2010}

Sivin I, Batár I. State-of-the-art of non-hormonal methods of contraception: III. Intrauterine devices. European Journal of Contraception and Reproductive Health Care 2010;15(2): 96-112.

\section{Skouby 2004}

Skouby SO. Contraceptive use and behavior in the 21 st century: a comprehensive study across five European countries. European Journal of Contraception and Reproductive Health Care 2004;9(2):57-68.

\section{Trussell 200}

Trussell J. Contraceptive failure in the United States. Contraception 2004;70:89-96.

\section{Trussell 2009}

Trussell J. Understanding contraceptive failure. Best Practice \& Research. Clinical Obstetrics \& Gynaecology 2009;23(2): 199-209.

\section{United Nations 2008}

United Nations. World Contraceptive Use 2007. Department of Economic and Social Affairs, Population Division, 2008.

\section{United Nations 2009}

United Nations. World Ccontraceptive Use 2009.

Department of Economic and Social Affairs, Population Division, 2009.

\section{Wellings 2007}

Wellings K, Zhihong Z, Krentel A, Barrett G, Glasier A. Attitudes towards long-acting reversible methods of contraception in general practice in the UK. Contraception 2007;76(3):208-14.

* Indicates the major publication for the study 


\section{CHARACTERISTICS OF STUDIES}

\section{Characteristics of included studies [ordered by study ID]}

\section{Bashour 2008}

\begin{tabular}{ll}
\hline Methods & $\begin{array}{l}\text { Randomised controlled trial with } 3 \text { study arms; outcomes assessed at } 4 \text { months postpar- } \\
\text { tum }\end{array}$ \\
\hline Participants & $\begin{array}{l}\text { Women who recently gave birth at the maternity teaching hospital in Damascus, Syria, } \\
\text { and who were available for follow-up over } 6 \text { months; women who delivered prematurely } \\
\text { or had babies with low birth weight }(<2500 \mathrm{~g}) \text { were excluded }\end{array}$ \\
\hline Interventions & $\begin{array}{l}\text { Home visits by midwives to examine, follow up, educate, support and counsel women } \\
\text { who had recently given birth } \\
\text { Group A: } 4 \text { visits on days } 1,3,7 \text { and } 30 \text { following delivery (285 women of } 301 \text { eligible, } \\
15 \text { excluded for bad address and } 1 \text { refused) } \\
\text { Group B: } 1 \text { visit on day } 3 \text { (294 women of } 301 \text { eligible, } 3 \text { excluded for bad address and } \\
4 \text { refused) } \\
\text { Group C: no visits (297 of } 301 \text { eligible, } 4 \text { refused) }\end{array}$ \\
\hline
\end{tabular}

Outcomes

Maternal postpartum morbidities; postnatal care uptake; contraceptive uptake and type; infant immunisation, feeding and morbidities

Notes

Risk of bias

\begin{tabular}{|c|c|c|}
\hline Bias & Authors' judgement & Support for judgement \\
\hline $\begin{array}{l}\text { Random sequence generation (selection } \\
\text { bias) }\end{array}$ & Low risk & $\begin{array}{l}\text { "Randomising was in blocks of } 7 \text { where a } \\
\text { caseload of } 21 \text { eligible deliveries per day was } \\
\text { assumed." }\end{array}$ \\
\hline Allocation concealment (selection bias) & Low risk & $\begin{array}{l}\text { "the random allocation relied on numbered } \\
\text { opaque and sealed envelopes." }\end{array}$ \\
\hline $\begin{array}{l}\text { Blinding of participants and personnel } \\
\text { (performance bias) } \\
\text { All outcomes }\end{array}$ & Unclear risk & $\begin{array}{l}\text { Participants were blinded, however, the } \\
\text { midwives who carried out the home visits } \\
\text { were not blinded }\end{array}$ \\
\hline $\begin{array}{l}\text { Blinding of outcome assessment (detection } \\
\text { bias) } \\
\text { All outcomes }\end{array}$ & Low risk & $\begin{array}{l}\text { The outcome assessors were blinded. Al- } \\
\text { though they could tell from the interviews, } \\
\text { they were not fully aware of the study ob- } \\
\text { jectives }\end{array}$ \\
\hline $\begin{array}{l}\text { Incomplete outcome data (attrition bias) } \\
\text { All outcomes }\end{array}$ & Low risk & $\begin{array}{l}\text { Of } 903 \text { women recruited, } 876 \text { completed } \\
\text { the study; } 3 \% \text { losses were due to refusals } \\
(\mathrm{N}=9) \text { and bad addresses }(\mathrm{N}=18) \text {, most } \\
\text { of whom were from Group } \mathrm{A}\end{array}$ \\
\hline
\end{tabular}


Bashour 2008 (Continued)

\begin{tabular}{|c|c|c|}
\hline Selective reporting (reporting bias) & Low risk & $\begin{array}{l}\text { Analysis and reporting was comprehensive; } \\
\text { all outcomes measured were reported }\end{array}$ \\
\hline Other bias & Unclear risk & $\begin{array}{l}\text { The power calculation was based on haem- } \\
\text { orrhoids, to detect decrease in this morbid- } \\
\text { ity from } 15 \% \text { in nonexposed group to } 7 \% \\
\text { in the exposed group }\end{array}$ \\
\hline
\end{tabular}

\section{Douthwaite 2005}

Methods

Participants
Controlled before and after study; evaluation conducted 6 years after the programme began; only those with a minimum of 4 years of intervention were eligible for inclusion in the sample

Women of reproductive age living in rural Pakistan. Women with no children were excluded due to lack of data on whether or not they wanted children $(\mathrm{N}=4277,931$ in non-intervention control group and 3346 in the intervention group); women using sterilisations are excluded

Community-based family planning programme using outreach workers (Lady Health Workers - LHWs) to provide a doorstep family planning service which included motivating women to practice family planning, providing oral contraceptive pills and condoms, and referring for injectables, IUD and sterilisation

Outcomes

Use of reversible modern contraceptive methods: oral contraceptive pills, injectables, condom and IUD

\section{Notes}

Women in the intervention group seemed to be better off than those in the control group; socio-economic indicators for the control and intervention groups showed that $27 \%$ of those in intervention group were literate whereas only $14 \%$ of the control group were. Also the proportion of those who were able to make decisions was higher in the intervention group

\section{Risk of bias}

\begin{tabular}{|c|c|c|}
\hline Bias & Authors' judgement & Support for judgement \\
\hline $\begin{array}{l}\text { Random sequence generation (selection } \\
\text { bias) }\end{array}$ & High risk & $\begin{array}{l}\text { Two LHWs were randomly selected and a } \\
\text { sample of } 8 \text { households was drawn from } \\
\text { each of the selected LHWs. Attempted } \\
\text { matching between control and interven- } \\
\text { tion groups, however, it was a non-random } \\
\text { sample selection for the control group }\end{array}$ \\
\hline Allocation concealment (selection bias) & High risk & Not stated \\
\hline
\end{tabular}


Douthwaite 2005 (Continued)

\begin{tabular}{|c|c|c|}
\hline $\begin{array}{l}\text { Blinding of participants and personnel } \\
\text { (performance bias) } \\
\text { All outcomes }\end{array}$ & Unclear risk & $\begin{array}{l}\text { No evidence of blinding and unlikely given } \\
\text { nature of the intervention }\end{array}$ \\
\hline $\begin{array}{l}\text { Blinding of outcome assessment (detection } \\
\text { bias) } \\
\text { All outcomes }\end{array}$ & High risk & $\begin{array}{l}\text { No information on blinding. The inter- } \\
\text { views were conducted with LHWs, house- } \\
\text { holds that they serve, as well as supervisors } \\
\text { and key staff at the health facilities to which } \\
\text { the LHWs are attached }\end{array}$ \\
\hline $\begin{array}{l}\text { Incomplete outcome data (attrition bias) } \\
\text { All outcomes }\end{array}$ & Low risk & $\begin{array}{l}\text { No applicable, however, no information on } \\
\text { non-response or those who declined to par- } \\
\text { ticipate }\end{array}$ \\
\hline Selective reporting (reporting bias) & Low risk & Probably all reported \\
\hline Other bias & Low risk & $\begin{array}{l}\text { Logistic regression used to control the dif- } \\
\text { ferences in the socio-economic factors }\end{array}$ \\
\hline
\end{tabular}

\section{Ferreira 2010}

Methods

A prospective randomised controlled trial with a parallel group conducted in July 2008 to September 2009; 6-month follow-up interview using the same questionnaire for the intervention and control groups

Pomen of reproductive age who had an abortion at public maternities in Recife, Brazil;
women were recruited within 1 to 2 weeks after the abortion and followed for a period
of 6 months; 246 eligible and agreed to participate, 123 allocated to intervention and
123 allocated to control group

Interventions

The intervention was personalised and comprehensive (face-to-face) contraceptive counselling ( 30 minutes) by trained providers on education and information about fertility after abortion, contraceptive methods, future plans to use contraceptives, and experience with last method; also free provision of the chosen method and verification of understanding of its use

Standard care is 30 to 40 minutes educational group counselling (approximately 20 to 25 women) by specialised nursing staff on contraceptive methods and their side effects, followed by a visit to the gynaecologist and supply of the chosen method

Outcomes

Primary outcomes: contraceptive acceptability and chosen method, use of contraceptives during 6-month follow-up period and consistent and correct use

Secondary outcomes: satisfaction with the method and pregnancies

Notes

\section{Risk of bias}


Ferreira 2010 (Continued)

\begin{tabular}{l|l|l}
$\begin{array}{l}\text { Random sequence generation (selection } \\
\text { bias) }\end{array}$ & Low risk & $\begin{array}{l}\text { "women were allocated through a sim- } \\
\text { ple randomisation method using random } \\
\text { number tables by independent statistician" } \\
\text { Note: probably done }\end{array}$ \\
\hline $\begin{array}{l}\text { Allocation concealment (selection bias) } \\
\text { Low risk }\end{array}$ & $\begin{array}{l}\text { Women were not aware of their assign- } \\
\text { ments and the provider was informed about } \\
\text { the allocation after the admission interview }\end{array}$ \\
\hline $\begin{array}{l}\text { Blinding of participants and personnel } \\
\text { (performance bias) } \\
\text { All outcomes }\end{array}$ & Unclear risk & $\begin{array}{l}\text { There was no information on blinding and } \\
\text { it is unlikely that participants and providers } \\
\text { are unaware given the nature of the inter- } \\
\text { vention }\end{array}$ \\
\hline
\end{tabular}

Blinding of outcome assessment (detection Low risk bias)

Follow-up by trained gynaecologist who

All outcomes was blinded to the study arms

\begin{tabular}{l|l|l}
\hline $\begin{array}{l}\text { Incomplete outcome data (attrition bias) } \\
\text { All outcomes }\end{array}$ & High risk & $\begin{array}{l}\text { Total of } 4 \text { lost to follow-up, all in the con- } \\
\text { trol group; also high discontinuation rate } \\
\text { (45\%) from control group (55/123) and 2/ } \\
123 \text { discontinued the intervention group }\end{array}$ \\
\hline Selective reporting (reporting bias) & High risk & $\begin{array}{l}\text { Intention-to-treat analysis was undertaken } \\
\text { and there was no information on the dif- } \\
\text { ference between those who continued with } \\
\text { the group counselling within the control } \\
\text { group and those who did not }\end{array}$ \\
\hline Other bias & Low risk & No other biases noted \\
\hline
\end{tabular}

\section{Jahanfar 2005}

\begin{tabular}{ll} 
Methods & $\begin{array}{l}\text { Controlled trial; stratified random sampling using variables: age, occupation, level of } \\
\text { education and number of children }\end{array}$ \\
\hline Participants & $\begin{array}{l}\text { Non-pregnant married women aged between } 15 \text { and } 45 \text { years (100 in the intervention } \\
\text { group and } 200 \text { in the control group) living in Hamedan City, Iran }\end{array}$ \\
\hline Interventions & $\begin{array}{l}\text { Community-based distribution }(\mathrm{CBD}) \text { programme which provided } 5 \text { community health } \\
\text { worker visits in } 2 \text { months for contraceptive counselling, and oral contraceptive pills, } \\
\text { condoms or injectables were given if required; those who chose IUD or permanent } \\
\text { methods were referred to the nearest family planning clinic with a referral letter. The } \\
\text { control group received } 2 \text { midwife visits in } 6 \text { months, no contraceptives were provided; } \\
\text { however they did have access to a Family Planning Clinic }\end{array}$
\end{tabular}


Jahanfar 2005 (Continued)

Notes

Risk of bias

\begin{tabular}{l|l|l}
\hline Bias & Authors' judgement & Support for judgement \\
\hline $\begin{array}{l}\text { Random sequence generation (selection } \\
\text { bias) }\end{array}$ & Low risk & $\begin{array}{l}\text { "A stratified random sampling technique } \\
\text { was adopted" } \\
\text { Note: probably done }\end{array}$ \\
\hline Allocation concealment (selection bias) & Unclear risk & $\begin{array}{l}\text { Sampling was based on age, occupation, } \\
\text { level of education and number of children; } \\
\text { however, no information on concealment } \\
\text { was provided }\end{array}$ \\
\hline
\end{tabular}

Blinding of participants and personnel High risk (performance bias)

Personnel not blinded, the midwife visited All outcomes

\begin{tabular}{l|l|l}
\hline $\begin{array}{l}\text { Blinding of outcome assessment (detection } \\
\text { bias) } \\
\text { All outcomes }\end{array}$ & High risk & $\begin{array}{l}\text { The midwife who trained community } \\
\text { health workers for the intervention also vis- } \\
\text { ited the control group and collected data }\end{array}$ \\
\hline $\begin{array}{l}\text { Incomplete outcome data (attrition bias) } \\
\text { All outcomes }\end{array}$ & Low risk & $\begin{array}{l}\text { Small number lost to follow-up }(3 / 200 \text { in } \\
\text { control) }\end{array}$ \\
\hline Selective reporting (reporting bias) & Unclear risk & $\begin{array}{l}\text { Not clear how the contraceptive continu- } \\
\text { ation rate was measured, whether it was } \\
\text { looked at for each visit or just during the } \\
\text { last. Also, there were no specific continua- } \\
\text { tion rates for each method reported, only } \\
\text { overall continuation of contraceptive usage } \\
\text { was reported } 98.9 \% \text { in the intervention } \\
\text { group and } 84.5 \% \text { in the control group with } \\
\text { P }<0.0001)\end{array}$ \\
\hline Other bias & Unclear risk & $\begin{array}{l}\text { Sample size power calculation was not re- } \\
\text { ported; it was stated that the study pro- } \\
\text { posed to reduce unwanted pregnancy from } \\
25 \% \text { to 10\%, however, it was not clear } \\
\text { whether the sample size calculation was } \\
\text { based on this }\end{array}$ \\
\hline
\end{tabular}


Kambo 1994

\begin{tabular}{l|l} 
Methods & $\begin{array}{l}\text { Before and after comparison, cross-sectional study with intervention and non-interven- } \\
\text { tion groups }\end{array}$ \\
\hline Participants & $\begin{array}{l}\text { Married women aged } 15 \text { to } 45 \text { years old (1000 in intervention group, } 850 \text { in control } \\
\text { group) living in Uttar Pradesh, India; average age for the } 2 \text { groups was } 29 \text { years old; } \\
\text { literacy rate for the non-intervention group was slightly higher, at 29\%, than intervention } \\
\text { group, at } 23 \%\end{array}$ \\
\hline
\end{tabular}

Provision of contraceptive counselling, distribution of condoms and oral contraceptives
by trained traditional practitioners. Traditional medical practitioners received training
on human reproduction, family planning methods including their use, side effects and
management, a referral system and other relevant user and provider information; the
training emphasised motivational and counselling skills. Over the 2-year intervention
period, the trained practitioners counselled on suitable methods, distributed condoms
and oral contraceptives, referred clients who chose an IUD or sterilisation to a clinic,
followed up and treated them for minor side effects or referred them for major compli-
cations

Outcomes

Knowledge and use of modern contraceptive methods

Notes

\section{Risk of bias}

\begin{tabular}{|c|c|c|}
\hline Bias & Authors' judgement & Support for judgement \\
\hline $\begin{array}{l}\text { Random sequence generation (selection } \\
\text { bias) }\end{array}$ & Low risk & $\begin{array}{l}\text { "Two blocks were selected and were as- } \\
\text { cribed to the intervention and noninter- } \\
\text { vention Primary Health Centre blocks." } \\
\text { "Fifty households were selected by system- } \\
\text { atic random sampling from intervention } \\
\text { and nonintervention villages." } \\
\text { Note: probably done }\end{array}$ \\
\hline
\end{tabular}

Allocation concealment (selection bias) High risk

No allocation information given and it is highly unlikely to be concealed

Blinding of participants and personnel Unclear risk (performance bias)

All outcomes

No information on blinding of personnel, however may not be possible due to the nature of intervention

Blinding of outcome assessment (detection Unclear risk bias)

All outcomes

Incomplete outcome data (attrition bias) High risk All outcomes
It was not clear whether the Traditional Medical Practitioners (the intervention) were the ones who carried out the data collection or whether it was done by independent researchers

$200(20 \%)$ lost to follow-up from the intervention group because trained practition- 
Kambo 1994 (Continued)

ers dropped out in 4 intervention villages

\begin{tabular}{|c|c|c|}
\hline Selective reporting (reporting bias) & Unclear risk & $\begin{array}{l}\text { There was a considerable gap ( } 7 \text { years) be- } \\
\text { tween the end of the study and publication } \\
\text { of the article }\end{array}$ \\
\hline Other bias & Low risk & No other risk of bias noted \\
\hline
\end{tabular}

Saeed 2008

\begin{tabular}{l|l}
\hline Methods & Randomised controlled trial, blinded; follow-up at 8 to 12 weeks postnatal \\
\hline Participants & $\begin{array}{l}\text { Postpartum (women admitted to the labour ward and who recently delivered), 299 } \\
\text { women in the intervention group and } 301 \text { women in the control group }\end{array}$ \\
\hline Interventions & $\begin{array}{l}\text { The intervention group received a 20-minute informal counselling session in the presence } \\
\text { of their husbands or a close relative as well as a simple one-page leaflet containing the } \\
\text { basic information on contraceptive methods at the time of discharge. The control group } \\
\text { received no counselling session or leaflet }\end{array}$ \\
\hline Outcomes & Contraceptive methods used postpartum \\
\hline Notes & No information on power and sample size
\end{tabular}

Risk of bias

\begin{tabular}{|c|c|c|}
\hline Bias & Authors' judgement & Support for judgement \\
\hline $\begin{array}{l}\text { Random sequence generation (selection } \\
\text { bias) }\end{array}$ & Low risk & $\begin{array}{l}\text { "Women were randomised into two groups } \\
\text { (A and B) by a block of four randomisation } \\
\text { charts" } \\
\text { Note: probably done }\end{array}$ \\
\hline Allocation concealment (selection bias) & Low risk & $\begin{array}{l}\text { "There was thorough concealment of allo- } \\
\text { cation, and similar characteristics were evi- } \\
\text { dent in the responders for the different lev- } \\
\text { els of each factor." } \\
\text { Note: probably done, however, no detail on } \\
\text { how "thorough concealment of allocation" } \\
\text { was performed }\end{array}$ \\
\hline
\end{tabular}

Blinding of participants and personnel Unclear risk (performance bias)

All outcomes
It is possible that participants were aware of which study arm they were in, as those in the intervention group were counselled with their husband or close relative 


\section{Saeed 2008 (Continued)}

\begin{tabular}{l|l|l}
$\begin{array}{l}\text { Blinding of outcome assessment (detection } \\
\text { bias) } \\
\text { All outcomes }\end{array}$ & Low risk & $\begin{array}{l}\text { The physician recording the follow-up data } \\
\text { was blinded and not aware of which study } \\
\text { arms the women belonged to }\end{array}$ \\
\hline $\begin{array}{l}\text { Incomplete outcome data (attrition bias) } \\
\text { All outcomes }\end{array}$ & Unclear risk & $\begin{array}{l}\text { Although the authors mentioned that there } \\
\text { was no bias, there were } 48 \text { lost to follow- } \\
\text { up and it was not specified how many were } \\
\text { from each group. There was no explanation } \\
\text { of reasons for loss to follow-up }\end{array}$ \\
\hline Selective reporting (reporting bias) & High risk & $\begin{array}{l}\text { Parity reported as } 2 \text { to } 5 \text { being highest fre- } \\
\text { quency in both groups; it is a wide range } \\
\text { for parity as the woman's or her partner's } \\
\text { desire for having another child many differ } \\
\text { between those already with } 5 \text { children and } \\
\text { those who had 2. Also outcome measures } \\
\text { were not specified. Knowledge of contra- } \\
\text { ception was mentioned in the aim and re- } \\
\text { ported for the baseline; however, it was not } \\
\text { reported, or possibly not measured, postin- } \\
\text { tervention }\end{array}$ \\
\hline
\end{tabular}

\section{Schunmann 2006}

Methods

Participants

Interventions

Notes

Risk of bias
Randomised controlled trial, blinded; the randomisation was by weeks

Women who underwent termination of pregnancy at the Royal Infirmary of Edinburgh, Scotland; 613 were randomised to intervention group $(\mathrm{n}=316)$ and standard care $(\mathrm{n}=$ 297)

Specialist contraceptive advice and enhanced provision; standard care included brief contraception discussion, provision of pills (1-month supply), condoms, IUD/IUS insertion or referrals; in addition to standard care, intervention group received 3 months supply of pills, implants if chosen, an appointment or firm arrangement for insertion of IUD/ IUS if not inserted before discharge

Contraceptive method uptake and continuation at 16 weeks; repeat abortion rate after 2 years through case notes review

Bias

Support for judgement 
Schunmann 2006 (Continued)

\begin{tabular}{|c|c|c|}
\hline $\begin{array}{l}\text { Random sequence generation (selection } \\
\text { bias) }\end{array}$ & Low risk & $\begin{array}{l}\text { "calendar weeks were randomised by the } \\
\text { statistician using random number tables" } \\
\text { Note: probably done }\end{array}$ \\
\hline Allocation concealment (selection bias) & Unclear risk & $\begin{array}{l}\text { It was stated that the unit staff was in- } \\
\text { formed verbally on the first day of each } \\
\text { working week whether it was a control or } \\
\text { intervention week }\end{array}$ \\
\hline
\end{tabular}

Blinding of participants and personnel Unclear risk (performance bias)

No information on blinding of personnel

All outcomes

Blinding of outcome assessment (detection Low risk bias)

All outcomes

All outcomes

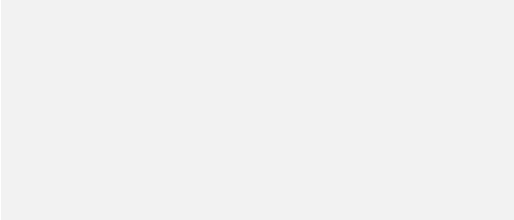

\begin{tabular}{ll}
\hline Selective reporting (reporting bias) $\quad$ Low risk
\end{tabular}

\begin{tabular}{|l|l}
\hline Other bias & $\begin{array}{l}\text { Unclear risk } \\
\text { the profile of those who declined to partic- } \\
\text { ipate in the study }\end{array}$ \\
\hline & $\begin{array}{l}\text { Significant differences between those who } \\
\text { responded to the 16-week follow-up and } \\
\text { those who did not, particularly with regards } \\
\text { to previous abortion and education - those } \\
\text { who responded were less likely to have had } \\
\text { a previous abortion (16\% versus } 31 \%) \text { and } \\
\text { were more likely to have completed tertiary } \\
\text { education }(31 \% \text { versus } 11 \%)\end{array}$ \\
\hline
\end{tabular}

The baseline data collection for the control group is from case notes, and for the intervention group the data were collected from both interviews and case records. No information was provided on blinding of the people collecting data at 16 weeks followup

High loss to follow-up at the 16-week follow-up questionnaire: 117 in intervention group $(\mathrm{n}=316)$ and 119 in standard care $(n=297)$. However, the analysis for contraceptive uptake was based case notes, and characteristics of those lost to follow-up were analysed and compared with those who were not lost to follow-up

All outcomes were reported. Also reported the profile of those who declined to participate in the study those who did not particulaly with regards to previous abortion and education - those who responded were less likely to have had were more likely to have completed tertiary 
Smith 2002

\begin{tabular}{l|l} 
Methods & $\begin{array}{l}\text { Randomised controlled trial in } 3 \text { countries, People's Republic of Chian (Shanghai), South } \\
\text { Africa (Cape Town) and Scotland (Edinburgh) }\end{array}$ \\
\hline Participants & $\begin{array}{l}\text { Women attending antenatal clinics }(\mathrm{N}=1500,500 \text { women from each site, equally } \\
\text { divided between control and intervention groups) when they were between } 24 \text { and } 36 \\
\text { weeks gestation }\end{array}$ \\
\hline
\end{tabular}

Interventions
$\begin{aligned} & \text { Provision of expert contraceptive counselling during the antenatal period; intervention } \\ & \text { group received 20-minute counselling session tailored to the anticipated contraceptive } \\ & \text { needs of each individual woman who was then given appropriate written information to } \\ & \text { take home. Control group received standard local care with regard to contraceptive advice; } \\ & \text { contraception is not formally discussed at all during antenatal period in Edinburgh but } \\ & \text { it is discussed briefly during group antenatal classes in Shanghai and Cape Town }\end{aligned}$

Outcomes

Contraceptive uptake, recall of advice received, contraceptive use at 1-year follow-up and pregnancy at 1-year follow-up

Notes

Risk of bias

\begin{tabular}{l|l|l}
\hline Bias & Authors' judgement & Support for judgement \\
\hline $\begin{array}{l}\text { Random sequence generation (selection } \\
\text { bias) }\end{array}$ & Low risk & $\begin{array}{l}\text { "antenatal clinic sessions were randomised" } \\
\text { Note: probably done }\end{array}$ \\
\hline Allocation concealment (selection bias) & Unclear risk & Not specified how the allocation was made \\
\hline $\begin{array}{l}\text { Blinding of participants and personnel } \\
\text { (performance bias) }\end{array}$ & Unclear risk & $\begin{array}{l}\text { Not blinded, as both professionals and par- } \\
\text { ticipants will have to discuss contraception } \\
\text { during antenatal sessions }\end{array}$ \\
\hline $\begin{array}{l}\text { Blinding of outcome assessment (detection } \\
\text { bias) } \\
\text { All outcomes }\end{array}$ & Unclear risk & $\begin{array}{l}\text { It is not clear whether the follow-ups at } 16 \\
\text { weeks and } 1 \text { year after birth were conducted } \\
\text { by the same nurse who carried out the in- } \\
\text { tervention }\end{array}$ \\
\hline $\begin{array}{l}\text { Incomplete outcome data (attrition bias) } \\
\text { All outcomes }\end{array}$ & High risk & $\begin{array}{l}\text { High loss to follow-up in all centres ex- } \\
\text { cept Shanghai (33\% to } 38 \% \text { in Edinburgh, } \\
25 \% \text { to } 28 \% \text { in Cape Town, } 2 \% \text { to } 1 \% \text { in } \\
\text { Shanghai for the intervention and control } \\
\text { groups, respectively) }\end{array}$ \\
\hline
\end{tabular}


Smith 2002 (Continued)

\begin{tabular}{|c|c|c|}
\hline Other bias & Unclear risk & $\begin{array}{l}\text { Study design inconsistent across the } 3 \text { sites. } \\
\text { The Edinburgh site gave participants the } \\
\text { opportunity to decline additional contra- } \\
\text { ceptive counselling, however, authors ad- } \\
\text { dressed this issue }\end{array}$ \\
\hline
\end{tabular}

\section{Soliman 1999}

\begin{tabular}{l|l}
\hline Methods & Randomised controlled trial \\
\hline Participants & $\begin{array}{l}\text { Women in second trimester of pregnancy (N = 200,100 in intervention and } 100 \text { in } \\
\text { control group) at the antenatal clinics in Mansoura, Egypt }\end{array}$ \\
\hline Interventions & $\begin{array}{l}\text { Antenatal counselling sessions using 'GATHER' technique were provided to women and } \\
\text { their husbands; individual family planning counselling secessions given in } 3 \text { consecutive } \\
\text { secessions (1 hour each); counselling sessions covered the anatomy and function of the } \\
\text { female reproductive system, the purpose and benefits of family planning; and follow- } \\
\text { up visits, information on contraceptives; audiovisual aids such as flip charts, posters, } \\
\text { contraceptive methods and a pelvic model were also used }\end{array}$ \\
\hline
\end{tabular}

Outcomes

Knowledge and practice of contraception

Notes

\section{Risk of bias}

\begin{tabular}{|c|c|c|}
\hline Bias & Authors' judgement & Support for judgement \\
\hline $\begin{array}{l}\text { Random sequence generation (selection } \\
\text { bias) }\end{array}$ & High risk & $\begin{array}{l}\text { "women were randomly allocated to one of the two } \\
\text { groups" } \\
\text { Note: probably done, however, no information given on } \\
\text { the randomisation process }\end{array}$ \\
\hline Allocation concealment (selection bias) & Unclear risk & No information on the allocation process \\
\hline $\begin{array}{l}\text { Blinding of participants and personnel } \\
\text { (performance bias) } \\
\text { All outcomes }\end{array}$ & Unclear risk & $\begin{array}{l}\text { No information on blinding, it is highly unlikely that it } \\
\text { is blinded due to the nature of the intervention }\end{array}$ \\
\hline $\begin{array}{l}\text { Blinding of outcome assessment (detection } \\
\text { bias) } \\
\text { All outcomes }\end{array}$ & Unclear risk & Insufficient information \\
\hline $\begin{array}{l}\text { Incomplete outcome data (attrition bias) } \\
\text { All outcomes }\end{array}$ & Low risk & $\begin{array}{l}\text { There were no losses to follow-up; it appears that the } \\
\text { "defaulters" were followed up in their homes }\end{array}$ \\
\hline Selective reporting (reporting bias) & Unclear risk & Insufficient information \\
\hline
\end{tabular}


Soliman 1999 (Continued)

Other bias

High risk

No description or information on what constitutes the

"routine care of the clinic" for the control group

IUD: intrauterine device; IUS: intrauterine system; LHW: lady health worker

Characteristics of excluded studies [ordered by study ID]

\begin{tabular}{|c|c|}
\hline Study & Reason for exclusion \\
\hline Bender 2004 & $\begin{array}{l}\text { Clarified with the main author and found that IUD use may also include levonorgestrel-releasing } \\
\text { intrauterine device (LNG-IUD) not just copper IUD. No separate data on copper IUD use were available }\end{array}$ \\
\hline Bianchi-Demicheli 2003 & The study focus on TOP as an intervention \\
\hline Boise 2003 & No specific IUD outcome measure was reported \\
\hline Bolam 1998 & No specific IUD outcome was measured or reported \\
\hline Daniel 2008 & No specific contraceptive use (e.g. IUD) was reported \\
\hline El-Tagy 2003 & No comparison group (i.e. control or before intervention) \\
\hline Goodman 2008 & $\begin{array}{l}\text { The study compared between interval and postabortal insertions; no data were reported on the of uptake } \\
\text { of IUDs - only per month insertion rate was reported }\end{array}$ \\
\hline На 2003 & The study participants fell outside of the inclusion criteria, no IUD use reported \\
\hline На 2005 & The study participants fell outside of the inclusion criteria \\
\hline Hubacher 2006 & $\begin{array}{l}\text { The study participants fell outside of the inclusion criteria; the study outcomes measured provider's } \\
\text { monthly insertion rate }\end{array}$ \\
\hline Johnson 2002 & No specific IUD outcome measure was reported \\
\hline Langston 2010 & $\begin{array}{l}\text { No specific contraceptive method (e.g. IUD) outcome reported; uptake of methods for the intervention } \\
\text { and usual care (control) groups reported at aggregated level as: very effective methods, effective methods } \\
\text { and less effective methods }\end{array}$ \\
\hline Lee 2011 & No specific IUD outcome measure was reported \\
\hline Lou 2004 & No specific contraceptive use was measured except condoms \\
\hline Luck 2000 & No IUD use outcome was measured \\
\hline
\end{tabular}


(Continued)

\begin{tabular}{|c|c|}
\hline Masch 2008 & The study design fell outside the inclusion criteria; before and after study with no control group \\
\hline McCarraher 2010 & The study design fell outside the inclusion criteria; before and after study with no control group \\
\hline Nac, ar 2003 & No specific contraceptive methods used were reported; contraceptive methods used were aggregated \\
\hline Nobili 2006 & $\begin{array}{l}\text { No specific contraceptive methods used were reported; contraceptive methods used were aggregated into } \\
\text { 'effective method' and 'ineffective method' }\end{array}$ \\
\hline Ortayli 2001 & $\begin{array}{l}\text { No comparison group or control group in the study; the before and after study only measured the } \\
\text { participants' contraceptive use during the month of conception and the method started when leaving } \\
\text { the clinic }\end{array}$ \\
\hline PARTNERS Project 2000 & Specific contraceptive method usage was not reported \\
\hline Ponce 2000 & The study focused on sexually transmitted diseases (STD) risk factors and IUD choice \\
\hline Postlethwaite 2007 & Study participants fell outside of the inclusion criteria \\
\hline Rasch 2004 & No IUD outcome was reported; there was no comparison group \\
\hline Rose 2010 & $\begin{array}{l}\text { The study design is outside the inclusion criteria; a prospective note search before and after study, with } \\
\text { the control being the pre-intervention period, compared to the postintervention period }\end{array}$ \\
\hline Shrestha 2002 & The study design is outside of the inclusion criteria; it was before and after study with no control group \\
\hline Shrewood-Fabre 2002 & $\begin{array}{l}\text { The study evaluated overall impact of a contraception programme, of which only one intervention } \\
\text { (media campaigns) was within the eligibility criteria for participants; outcomes reported were for overall } \\
\text { programme and impact of media campaigns alone was not evaluated }\end{array}$ \\
\hline Stevens 1992 & No IUD outcome reported \\
\hline Sääv 2007 & $\begin{array}{l}\text { The study was for provision of sublingual misoprostol plus diclofenac prior to insertion of an IUD; } \\
\text { outcomes were the effect on cervical dilatation and side effects }\end{array}$ \\
\hline Thompson 2006 & $\begin{array}{l}\text { No specific contraceptive method (e.g. IUD) outcome was reported; all methods are aggregated under } \\
\text { "modern" methods }\end{array}$ \\
\hline Yassin 2005 & The study design fell outside of the inclusion criteria: it is a before and after study with no control group \\
\hline Zhu 2009 & No specific contraceptive methods used (e.g. IUD) were reported \\
\hline
\end{tabular}

IUD: intrauterine device; TOP: termination of pregnancy 


\section{Characteristics of ongoing studies [ordered by study ID]}

\section{Dulli 2010}

\begin{tabular}{ll}
\hline Trial name or title & $\begin{array}{l}\text { PPFPIZ (Postpartum Family Planning Services Through Enhanced Family Planning in Immunization Ser- } \\
\text { vices) }\end{array}$ \\
\hline Methods & Randomised controlled trial \\
\hline Participants & Women attending immunisation services for their infant \\
\hline Interventions & $\begin{array}{l}\text { Educational brochures, group education and individual counselling on the benefits of the health timing and } \\
\text { spacing of births, pregnancy risk and return to fertility during the extended postpartum period (12 months), } \\
\text { and referral to family planning services for those who are interested }\end{array}$ \\
\hline Outcomes & Use of a modern contraceptive method among postpartum women \\
\hline Starting date & February 2010 \\
\hline Contact information & Lisa S Dulli, Family Health International \\
\hline Notes & \\
\hline
\end{tabular}

\section{Norman 2010}

\begin{tabular}{ll}
\hline Trial name or title & Better Contraceptive Choices \\
\hline Methods & $\begin{array}{l}\text { Interventional multi-site randomised controlled trial. Randomisation by blocking (4) and stratified for parity } \\
\text { and study site }\end{array}$ \\
\hline Participants & $\begin{array}{l}\text { Women seeking a therapeutic abortion in their second trimester of pregnancy (over 12 weeks gestation) who } \\
\text { are interested in intrauterine contraception }\end{array}$ \\
\hline Interventions & Immediate insertion compared to a planned insertion at 4 weeks \\
\hline Outcomes & $\begin{array}{l}\text { Primary outcomes: pregnancy rate at one year } \\
\text { Secondary outcomes: 1. costs and cost effectiveness; 2. rates of loss to follow-up; 3. adverse events (such as } \\
\text { infection or perforation: anticipated at under 1\%); 4. expulsion; 5. continuation of method; 6. satisfaction } \\
\text { with IUD chosen and with insertion timing assigned }\end{array}$ \\
\hline Starting date & June 2010 \\
\hline Contact information & Wendy V. Norman, wvnorman@interchange.ubc.ca \\
\hline Notes & \\
\hline
\end{tabular}

IUD: intrauterine device 
DATA AND ANALYSES

Comparison 1. Effectiveness of community-based family planning programme: community workers versus control

\begin{tabular}{|c|c|c|c|c|}
\hline Outcome or subgroup title & $\begin{array}{l}\text { No. of } \\
\text { studies }\end{array}$ & $\begin{array}{c}\text { No. of } \\
\text { participants }\end{array}$ & Statistical method & Effect size \\
\hline 1 Uptake of IUD & 3 & 6224 & Peto Odds Ratio (Peto, Fixed, 95\% CI) & $2.00[1.40,2.85]$ \\
\hline 2 Knowledge of IUD & 1 & & Odds Ratio (M-H, Random, 95\% CI) & Subtotals only \\
\hline 2.1 Knowledge of method & 1 & 1650 & Odds Ratio (M-H, Random, 95\% CI) & $39.00[15.91,95.62]$ \\
\hline 2.2 Knowledge of availability & 1 & 1650 & Odds Ratio (M-H, Random, 95\% CI) & $2.68[2.19,3.27]$ \\
\hline
\end{tabular}

Comparison 2. Effectiveness of contraceptive counselling provision among postpartum population: postnatal counselling versus control

\begin{tabular}{|c|c|c|c|c|}
\hline Outcome or subgroup title & $\begin{array}{l}\text { No. of } \\
\text { studies }\end{array}$ & $\begin{array}{c}\text { No. of } \\
\text { participants }\end{array}$ & Statistical method & Effect size \\
\hline 1 Uptake of IUD & 2 & & Peto Odds Ratio (Peto, Fixed, 95\% CI) & Subtotals only \\
\hline $\begin{array}{l}1.1 \text { Counselling and leaflet } \\
\text { before discharge }\end{array}$ & 1 & 600 & Peto Odds Ratio (Peto, Fixed, 95\% CI) & $5.73[3.59,9.15]$ \\
\hline 1.2 Postnatal home visits & 1 & 849 & Peto Odds Ratio (Peto, Fixed, 95\% CI) & $1.60[0.90,2.85]$ \\
\hline
\end{tabular}

Comparison 3. Effectiveness of contraceptive counselling provision among postpartum population (short-term): antenatal counselling versus control

\begin{tabular}{lccll} 
Outcome or subgroup title & $\begin{array}{c}\text { No. of } \\
\text { studies }\end{array}$ & $\begin{array}{c}\text { No. of } \\
\text { participants }\end{array}$ & Statistical method & Effect size \\
\hline 1 Uptake of IUD & 2 & 1491 & Peto Odds Ratio (Peto, Fixed, 95\% CI) & $2.33[1.39,3.91]$ \\
1.1 Edinburgh & 1 & 385 & Peto Odds Ratio (Peto, Fixed, 95\% CI) & $1.26[0.36,4.45]$ \\
1.2 Shanghai & 1 & 517 & Peto Odds Ratio (Peto, Fixed, 95\% CI) & $0.90[0.32,2.52]$ \\
1.3 Cape Town & 1 & 389 & Peto Odds Ratio (Peto, Fixed, 95\% CI) & $0.0[0.0,0.0]$ \\
1.4 Mansoura & 1 & 200 & Peto Odds Ratio (Peto, Fixed, 95\% CI) & $4.22[2.14,8.32]$ \\
\hline
\end{tabular}


Comparison 4. Effectiveness of family planning counselling among postabortion population

\begin{tabular}{lcclc} 
Outcome or subgroup title & $\begin{array}{c}\text { No. of } \\
\text { studies }\end{array}$ & $\begin{array}{c}\text { No. of } \\
\text { participants }\end{array}$ & Statistical method & Effect size \\
\hline 1 Uptake of IUD & 2 & 855 & Peto Odds Ratio (Peto, Fixed, 95\% CI) & $1.39[0.68,2.83]$ \\
$\quad \begin{array}{l}\text { 1.1 IUD insertion } \\
\text { arrangement made vs no }\end{array}$ & 1 & 613 & Peto Odds Ratio (Peto, Fixed, 95\% CI) & $1.51[0.73,3.10]$ \\
$\begin{array}{l}\text { arrangement } \\
\quad \begin{array}{l}1.2 \text { One-to-one vs group } \\
\text { counselling }\end{array}\end{array}$ & 1 & 242 & Peto Odds Ratio (Peto, Fixed, 95\% CI) & $0.13[0.00,6.60]$ \\
\hline
\end{tabular}

\section{Analysis I.I. Comparison I Effectiveness of community-based family planning programme: community workers versus control, Outcome I Uptake of IUD.}

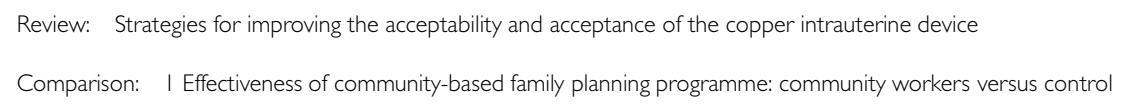

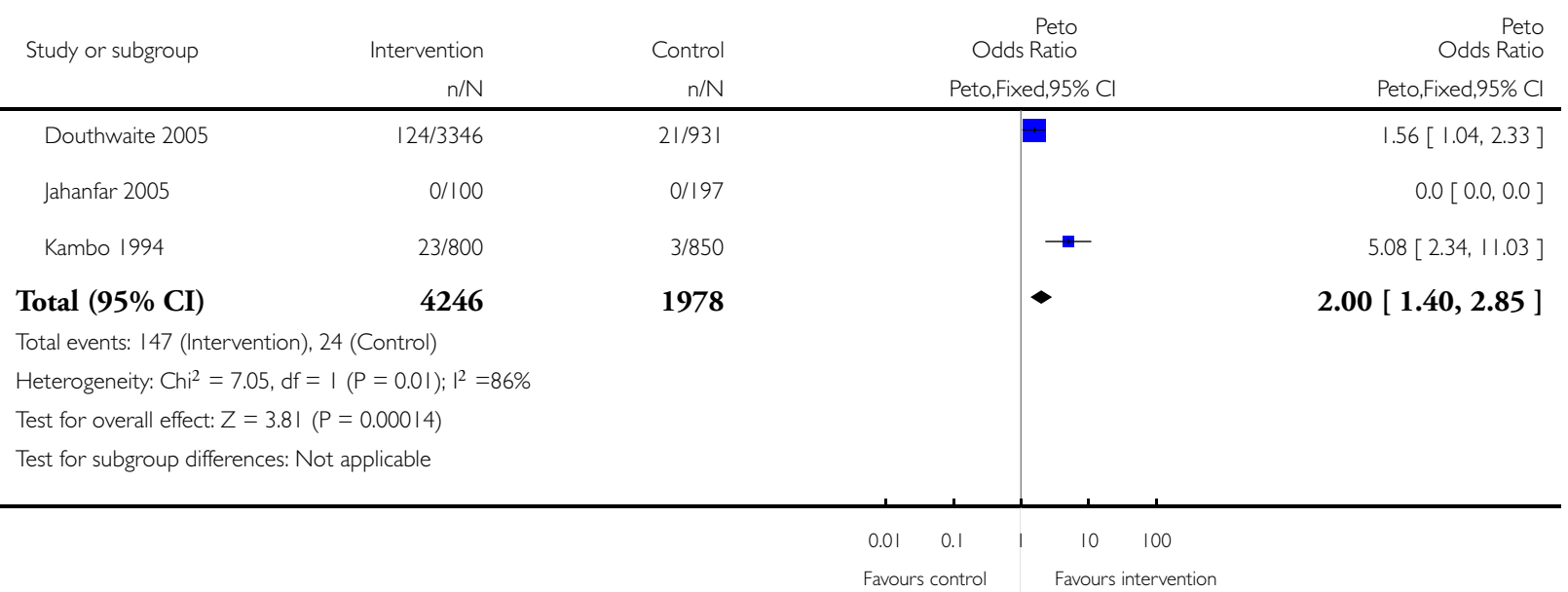


Analysis I.2. Comparison I Effectiveness of community-based family planning programme: community workers versus control, Outcome 2 Knowledge of IUD.

Review: Strategies for improving the acceptability and acceptance of the copper intrauterine device

Comparison: I Effectiveness of community-based family planning programme: community workers versus control

Outcome: 2 Knowledge of IUD

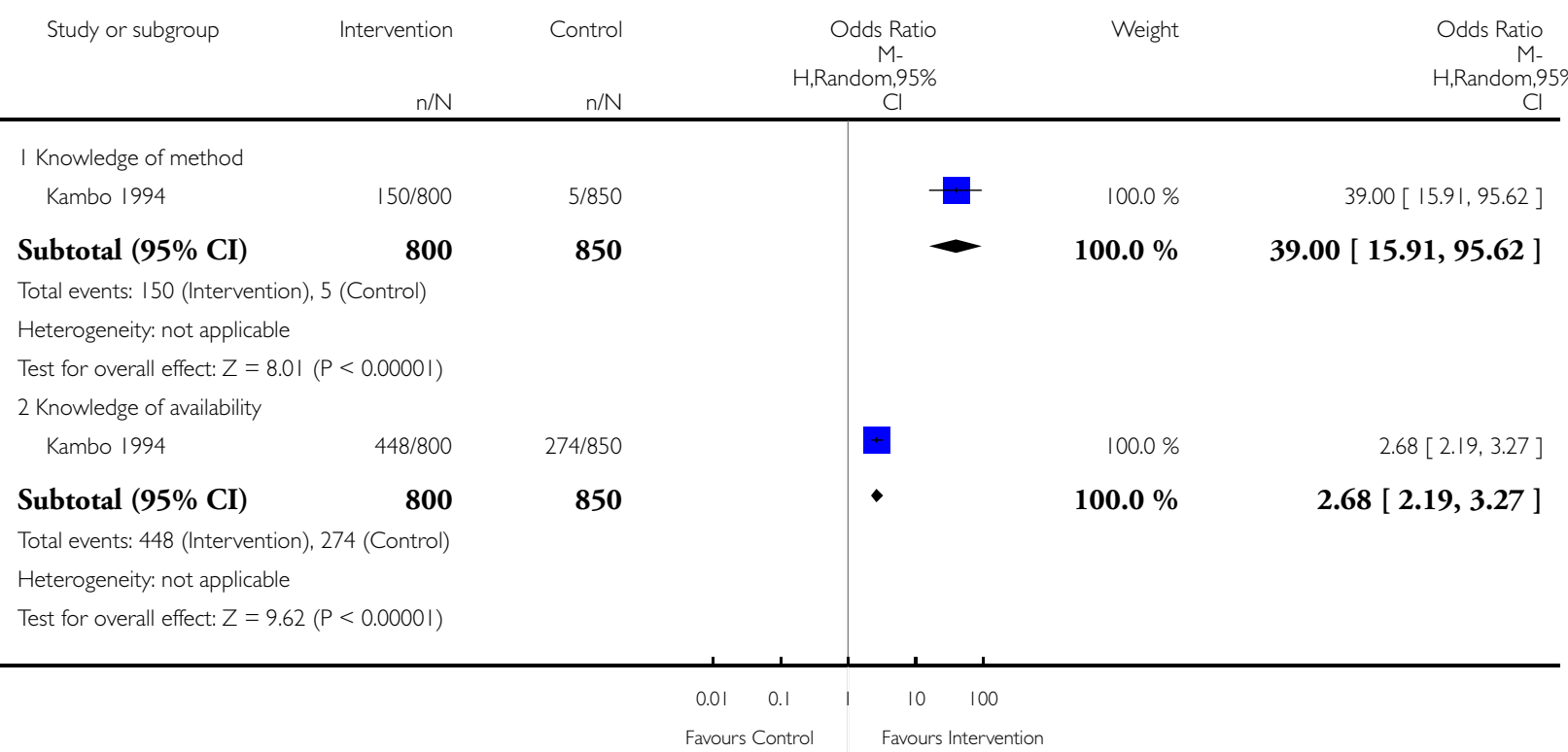


Analysis 2.I. Comparison 2 Effectiveness of contraceptive counselling provision among postpartum population: postnatal counselling versus control, Outcome I Uptake of IUD.

Review: Strategies for improving the acceptability and acceptance of the copper intrauterine device

Comparison: 2 Effectiveness of contraceptive counselling provision among postpartum population: postnatal counselling versus control

Outcome: I Uptake of IUD

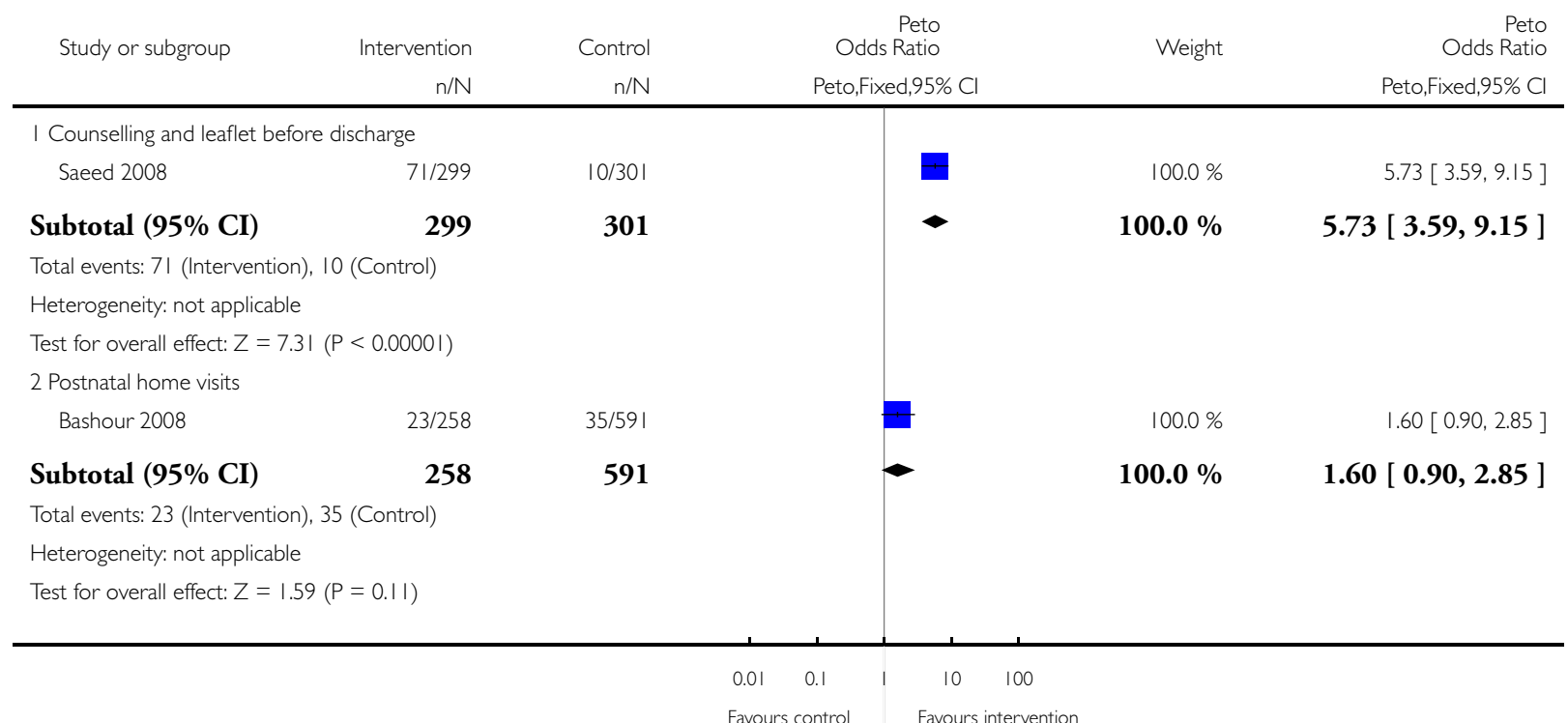


Analysis 3.I. Comparison 3 Effectiveness of contraceptive counselling provision among postpartum population (short-term): antenatal counselling versus control, Outcome I Uptake of IUD.

Review: Strategies for improving the acceptability and acceptance of the copper intrauterine device

Comparison: 3 Effectiveness of contraceptive counselling provision among postpartum population (short-term): antenatal counselling versus control

Outcome: I Uptake of IUD

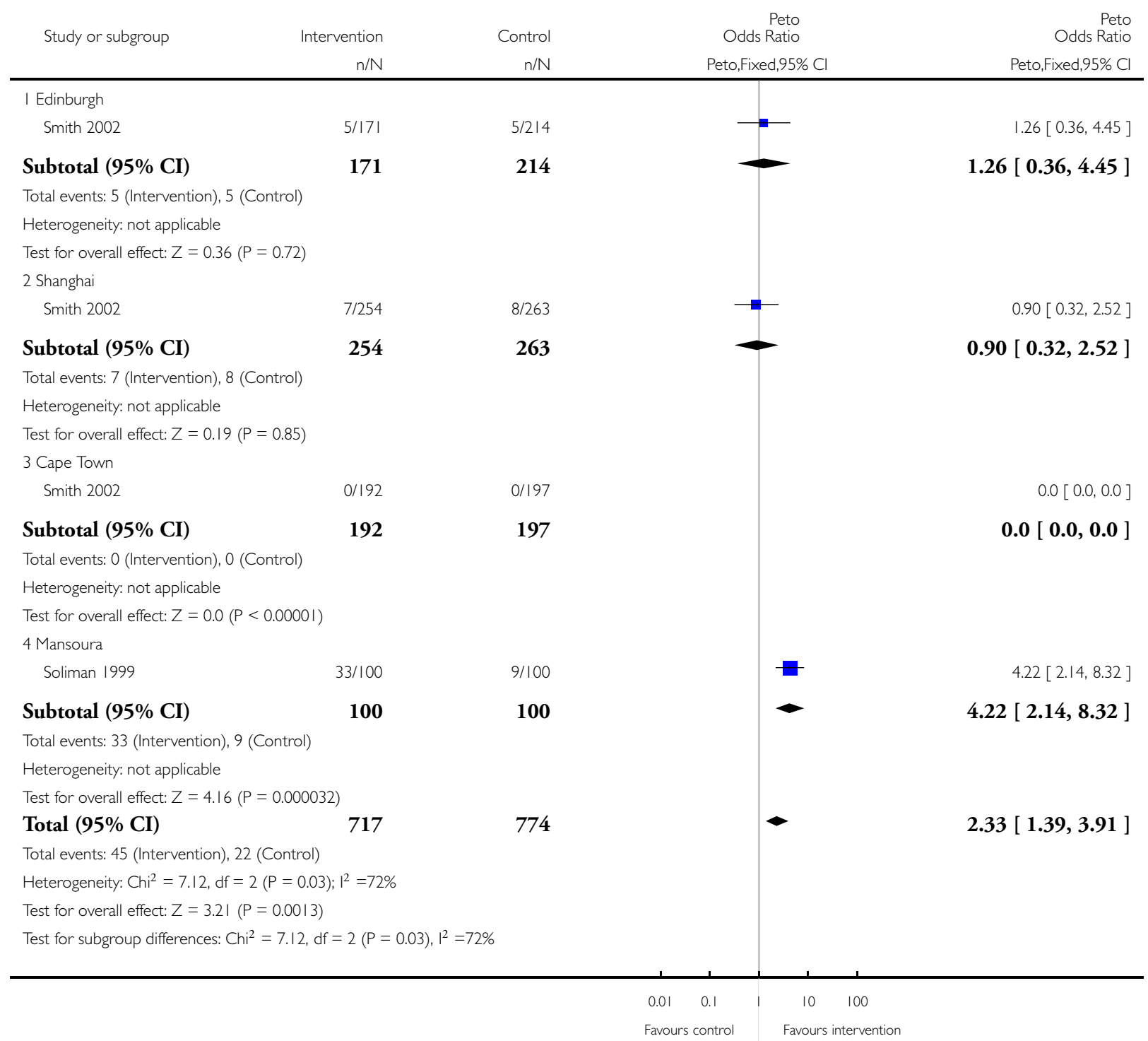


Analysis 4.I. Comparison 4 Effectiveness of family planning counselling among postabortion population, Outcome I Uptake of IUD.

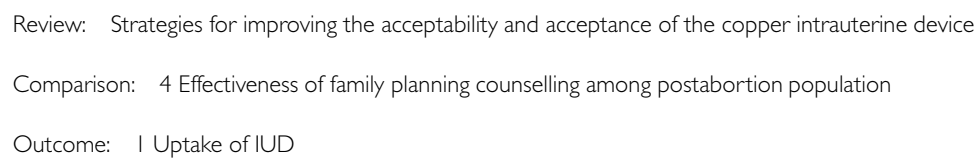

Total events: 19 (Intervention), 12 (Control)

Heterogeneity: not applicable

Test for overall effect: $Z=1.11(P=0.27)$

2 One-to-one vs group counselling

Total events: 0 (Intervention), I (Control)

Heterogeneity: not applicable

Test for overall effect: $Z=1.02(P=0.31)$

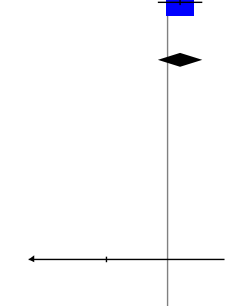

\section{H I S T O R Y}

Protocol first published: Issue 12, 2010

Review first published: Issue 3, 2012

\section{CONTRIBUTIONS OF AUTHORS}

All authors contributed to this systematic review. ME Arrowsmith and S Saxena conceived the review. ME Arrowsmith, CRH Aicken and S Saxena designed and planned the review, and submitted the protocol for review by the Cochrane Fertility Review Group. CRH Aicken and ME Arrowsmith identified eligible reports and extracted data independently. S Saxena verified the results and conclusions. A Majeed and S Saxena provided analytical and editorial input. 


\section{DECLARATIONS OF INTEREST}

None.

\section{SOURCES OF SUPPORT}

\section{Internal sources}

- Imperial College London, Department of Primary Care \& Public Health, UK.

The Department of Primary Care \& Public Health at Imperial College London is grateful for support from the NIHR Collaboration for Leadership in Applied Health Research \& Care (CLAHRC) Scheme, the NIHR Biomedical Research Centre scheme, and the Imperial Centre for Patient Safety and Service Quality.

\section{External sources}

- No sources of support supplied 